This item was submitted to Loughborough's Research Repository by the author.

Items in Figshare are protected by copyright, with all rights reserved, unless otherwise indicated.

\title{
Supply chain risk management: present and future scope
}

PLEASE CITE THE PUBLISHED VERSION

http://dx.doi.org/10.1108/09574091211289200

PUBLISHER

(C) Emerald Group Publishing Limited

VERSION

AM (Accepted Manuscript)

LICENCE

CC BY-NC-ND 4.0

REPOSITORY RECORD

Ghadge, Abhijeet, Samir Dani, and Roy S. Kalawsky. 2019. "Supply Chain Risk Management: Present and Future Scope". figshare. https://hdl.handle.net/2134/12624. 
This item was submitted to Loughborough's Institutional Repository (https://dspace.lboro.ac.uk/) by the author and is made available under the following Creative Commons Licence conditions.

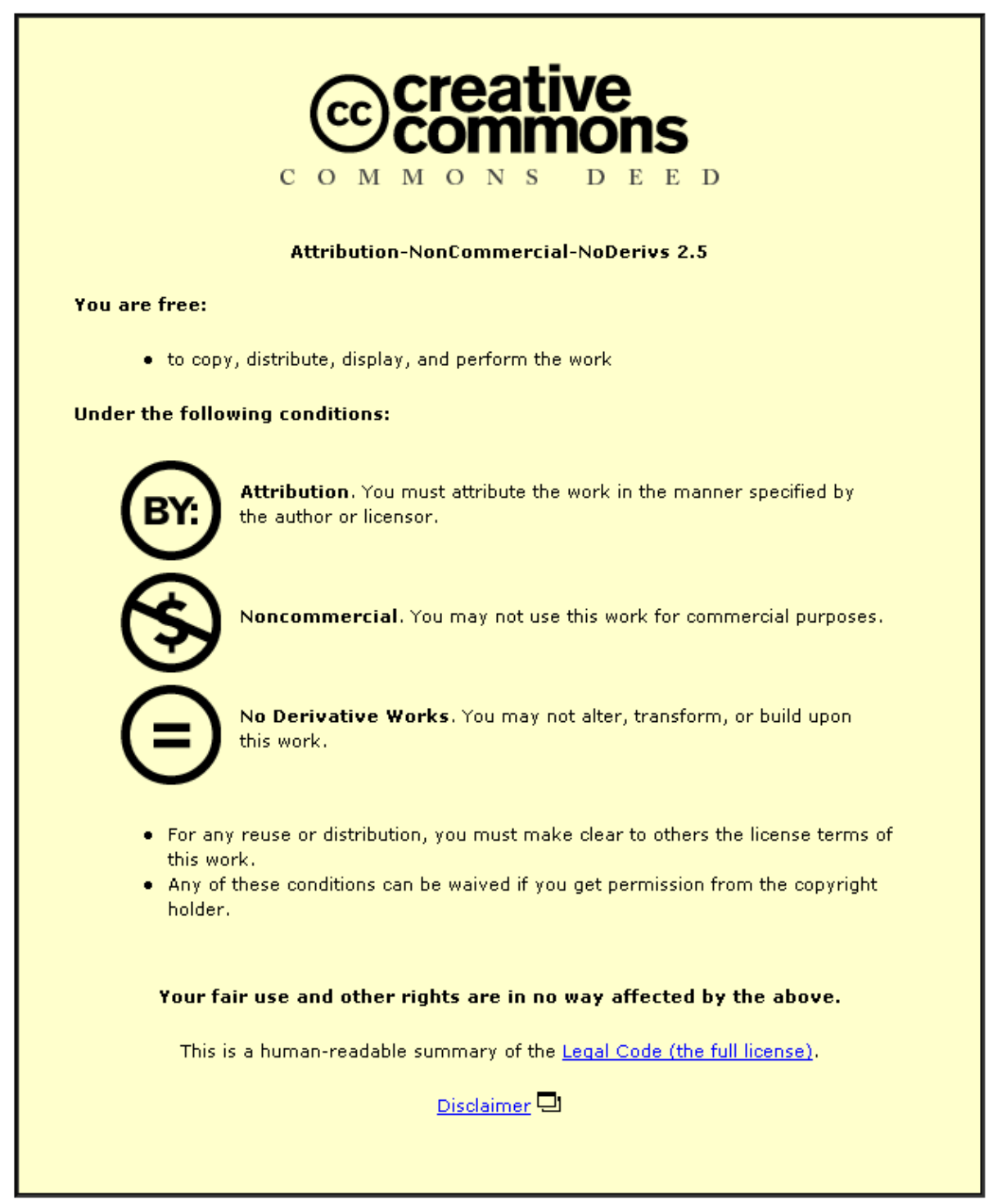

For the full text of this licence, please go to: http://creativecommons.org/licenses/by-nc-nd/2.5/ 


\section{Supply Chain Risk Management: Present and Future Scope}

\section{Purpose}

This paper examines Supply Chain Risk Management (SCRM) from a holistic systems thinking perspective by considering different typologies that have evolved as a result of earlier research. The aim of the research reported in this paper is the identification of important strategic changes in the field and to outline future requirements and research opportunities in SCRM.

\section{Design/methodology/approach}

The Systematic Literature Review (SLR) methodology employed by our research was used to evaluate and categorise a literature survey of quality articles published over a period of 10 years (2000-2010). Additionally, the findings from the SLR have been strengthened through cross validation against results obtained from an associated text mining activity.

\section{Findings}

The SLR methodology has provided a rich, unbiased and holistic picture of the advances in the field of SCRM. Consequently, important new research areas have been identified based on a multiperspective descriptive and thematic data analysis. In addition, our analysis based on evolved typologies indicates a growth of SCRM from a nascent to a fairly established activity over the past decade.

\section{Practical implications}

The systematic approach undertaken for the literature review will provide future researchers and managers with an insightful understanding of the scope of the SCRM field. Also, the literature review provides important clues on new research directions for SCRM through identification of gaps in current knowledge.

\section{Originality/value}

The holistic approach to SCRM was found to be an important missing link in earlier literature surveys. The outcome of the Systematic Literature Review reported in this paper has provided critical insights into the present and future scope of the SCRM field. The identified research insights, gaps and future directions will encourage new research techniques with a view to managing the risks in the globalized supply chain environment.

\section{Keywords}

Supply Chain Risk Management, Systematic Literature Review, Text Mining.

\section{Paper type}

Literature review

\section{INTRODUCTION}

Today's e-world has led to an information explosion from the countless data sources that appear on a daily basis. Supply Chain Risk Management (SCRM) is an area that has recently been receiving a great deal of interest from academics and practitioners. SCRM is believed to be in an emerging and promising new field by researchers (Sodhi et al., 2012) but has a number of open-ended boundaries in its scope. Various authors have carried out a literature review on SCRM at various stages over the last 10 years (e.g. Juttner et al., 2003; Vanany et al., 2009; Rao and Goldsby, 2009) who provide a good platform for researchers and practitioners trying to make sense of the on-going research and identify the current state-of-art. However, narrative literature reviews are believed to lack thoroughness and rigour (Tranfield et al., 2003). On the contrary, evidence based reviews are considered to be more thorough and transparent as they provide insights into the field by literature being analysed through a number of perspectives. The systematic review approach provides an evidence base for literature survey (Tranfield et al., 2003; Rousseau et al., 2008; Denyer and Tranfield, 2009). In this paper, a Systematic Literature Review (SLR) of the SCRM field is carried out by means of a structured process. SLR was first used in medical science and has expanded into the management field. The SLR 
process followed in our research has been adopted from the work done by Tranfield et al. (2003) for developing evidence-informed knowledge management. Knowledge management is defined as the systemic and managerial approach to gathering, management, analysis, discovery and sharing of knowledge in order to maximize performance (Chen, et. al., 2001). Data mining and text mining tools are extensively used for knowledge management, knowledge retrieval and scientific discovery as well as business analysis. The more advanced tools employ artificial intelligence techniques to analyse sets of numerical or textual data and discover new patterns to help inform our knowledge base. Consequently, text mining is rapidly becoming an important tool for comprehending the data through intelligent and automated data analysis. More recently, text mining has been found to be useful for supporting systematic reviews for quick and evidence based data discovery (Ananiadou et al., 2009).

The following sections provide an overview of the research field in terms of the background and current advances in SCRM. A more detailed research methodology for conducting a systematic literature review will be described later. The research behind the SLR approach has identified critical insights into SCRM research and is presented in the analysis and findings section of the paper. In addition, gaps in existing work for defining future scope of SCRM and opportunities for future research is presented in future research agenda section.

\section{SUPPLY CHAIN RISK MANAGEMENT}

Managing risks in the modern environment is becoming increasingly challenging (Christopher and Lee 2004), primarily because of uncertainties in supply and demand, global outsourcing and short product life cycles. Risk in this context can be defined as the potential for unwanted negative consequences that arise from an event or activity (Rowe, 1980). Today, the global business environment is influenced by financial instability, just-in-time outsourcing, company mergers, new technologies, ebusiness, shorter time-to-market, etc. thus forcing organizations to adopt new ways of doing business (Stefanovic et al., 2009). However, today's leaner, just-in-time globalized supply chains are more vulnerable than ever before due to operational and external (natural and man-made) disruptions. Vulnerability is defined as an exposure to serious disturbance arising from risks within the supply chain as well as risks external to the supply chain (Christopher and Peck, 2004).

Supply Chain (SC) risk can be broadly defined as an exposure to an event which causes disruption, thus affecting the efficient management of the supply chain network. Risk management is becoming an integral part of a holistic SCM design (Christopher and Lee, 2004). There is diverse classification of supply chain risks found in the literature. Risk itself can be termed as disruption, vulnerability, uncertainty, disaster, peril and hazard. Academic literature within the domain of supply chains has sought to differentiate between the various forms by focussing on the availability of information and the intensity of these events. Hence, this can range from the completely unknown to the completely known serious and immediate danger.

Vorst and Beulens (2002) define uncertainty as a situation for the supply chain where the decision maker lacks information about the supply chain network and the environment; and hence is unable to predict the impact of the event on supply chain behaviour. Although risk and uncertainty are interchangeably used in SC literature, according to Knight (1921) uncertainty is immeasurable as it lacks complete certainty and has more than one possibility. On the other hand, risk is measurable as it is an outcome of uncertainty with some of possibilities involving loss or other undesirable outcomes (Hubbard 2007, 2009). According to Williams et al. (2008) supply chain security is a subcomponent of overall risk management strategy within the organization.

\section{RESEARCH METHODOLOGY}

Our research follows the systematic literature review methodology which differs from traditional narrative reviews by adopting a 'replicable, scientific and transparent process' (Tranfield et al., 2003). We adopt the SLR process suggested and followed by Tranfield et al. (2003) for developing evidenceinformed knowledge management process. The adapted SLR process for identifying the scope of SCRM research is addressed in four distinctive phases as shown in Figure 1. Although the SLR methodology is not widely used within the management field, it has been found to have reasonable acceptance as a desired methodology in literature review by the researchers (Badger et al., 2000). Systematic review is normally done manually and is quite laborious. But, with the help of new knowledge management tools, the SLR process could be made simple, quick as well as evidence based. Text mining is used in this research for supporting a quick and evidence based data discovery process in conjunction with the manual process. Although the SLR method has been used sporadically within the supply chain domain, a recent special issue of the 'Supply Chain Management: An international journal' has been focussed on using SLR to build supply chain theory. In the same 
A. Ghadge, S. Dani and R. Kalawsky (2012), Supply Chain Risk Management: Present and Future Scope, International Journal of Logistics Management, Vol. 23 No. 3, pp. 313-339.

issue Colicchia and Strozzi (2012) have introduced a new methodology for SCRM using SLR and network analysis.

\section{Systematic identification of data sources}

The quality of SLR is driven by the data sources that are used for analysis. The preliminary stage of the SLR process is mainly an iterative process of definition, clarification and refinement of concepts (Clarke and Oxman, 2001). In this, databases are searched with manually constructed keywords commonly called 'search strings'. While managing SLR, it is necessary to assess the relevance of the literature and to delimit it by considering cross-disciplinary perspectives (Tranfield et al., 2003). Hence, inclusion and exclusion criterion are predefined for identification of the data sources.

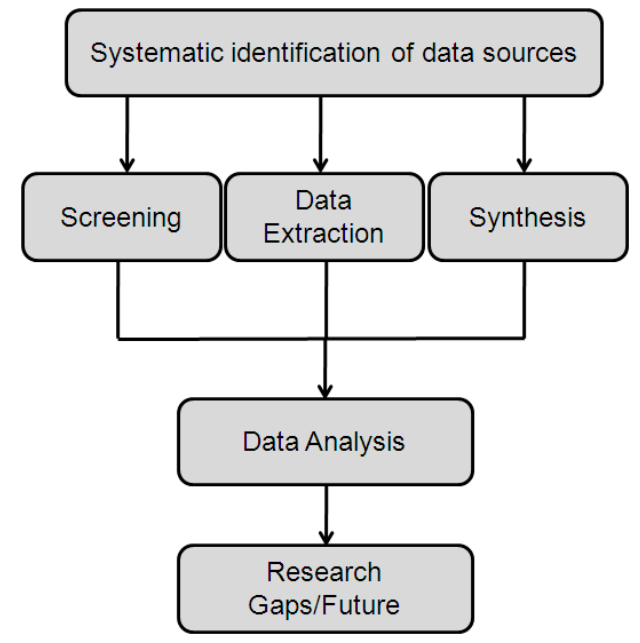

Figure 1: Systematic literature review process (adopted from Tranfield et. al., 2003)

\section{Screening, Data Extraction and Synthesis}

Comprehensive and unbiased search is one of the fundamental differences between a traditional narrative review and a systematic review (Lemmer et al., 1999; Tranfield et al., 2003). SLR screening is identification of quality data sources and is conducted using constructed search strings on available data sources. In order to develop a confidence on the data identified, it is preferred to rely on implicit quality rating of the academic journals rather than formally defining and applying any quality assessment criteria to different data sources (Tranfield et al., 2003). Text mining can be used to extract the important words and phrases automatically within set of documents identified during screening process. During text mining of documents, further cleaning of texts may be required to exclude the terms not useful for SLR. Research synthesis is term referred for a 'family of methods' used in review for analysing and summarising the findings (Davies, 2000).

\section{Data Analysis}

Data analysis is considered to be most rigorous process of all other processes in SLR. Selected data is analysed through several qualitative and quantitative tools like statistical analysis and citation/cocitation analysis. Text mining can be further used at this stage to support data analysis by calculating the word and phrase frequency. It is identified that, there is a strong relationship between word frequency and vital description in a document (Cruzes et al., 2007).

\section{Dissemination and Reporting}

Management research output can be presented in two stages. The first stage is a descriptive analysis providing a set of classification on various attributes used in data analysis. Later, findings of thematic analysis can be reported through aggregative and interpretative approaches. Dissemination of results can be represented in the form of research findings, gaps and future scope.

\section{DATA IDENTIFICATION}

Following the SLR process discussed in the previous section, a panel of expert's (mainly academic researchers) in field of SCRM were sought to provide directions for the literature survey. To identify research articles for conducting quality analysis it was decided to use quality rating of journals in Operations Management (OM), Operations Research (OR) and Management Science (MS) instead of 
A. Ghadge, S. Dani and R. Kalawsky (2012), Supply Chain Risk Management: Present and Future Scope, International Journal of Logistics Management, Vol. 23 No. 3, pp. 313-339.

developing our own quality assessment criteria. The Association of Business Schools (ABS), UK publishes quality rating of academic journals. These ABS ranked Journals were found to be vastly referred and accepted in the academic world. We strictly followed the journal quality rating provided in 'Journal Quality Guide' published by ABS and referred to only journals in the above mentioned areas with an average of $3^{*}$ quality rating in last two years $(2009,2010)$. Three $2^{*}$ quality rated journals were also included due to the large number of publications in the SCRM domain within the sample decade. Interestingly, these three Journals were also found to be heavily referred to in other $3^{*}$ and $4^{*}$ quality rated journals from the OM and OR/MS field. The methodology did not intend to create any bias by considering only the journals within the OM area however the SCRM area has been represented the most within this domain. It can be argued that to consider a holistic approach, it would have been pertinent to consider interdisciplinary journal sources, however since the unit of assessment is the 'supply chain' it was decided to focus holistically on factors that are considered within this domain. Figure 2 shows 15 identified data sources with their ABS ranking in OM and OR/MS areas.

\begin{tabular}{|c|c|c|c|}
\hline $\begin{array}{l}\text { SR. } \\
\text { No. }\end{array}$ & Subject field/area & List of Journals & $\begin{array}{c}\text { ABS } \\
\text { Ranking }\end{array}$ \\
\hline 1 & \multirow{10}{*}{$\begin{array}{l}\text { Operations } \\
\text { Management } \\
\text { (OM) }\end{array}$} & Journal of Operations Management (JOM) & 4 \\
\hline 2 & & Production and Operations Management (POM) & 3 \\
\hline 3 & & International Journal of Production Economics (IJPE) & 3 \\
\hline 4 & & International Journal of Operations and Production Management (IJOPM) & 3 \\
\hline 5 & & Supply Chain Management: An International Journal (SCMIJ) & 3 \\
\hline 6 & & International Journal of Production Research (IJPR) & 3 \\
\hline 7 & & Production Planning and Control (PPC) & 3 \\
\hline 8 & & International Journal of Logistics: Research and Applications (IJLRA) & 2 \\
\hline 9 & & International Journal of Logistics Management (IJLM) & 2 \\
\hline 10 & & International Journal of Physical Distribution and Logistics Management (IJPDLM) & 2 \\
\hline 11 & \multirow{5}{*}{$\begin{array}{c}\text { Operations } \\
\text { Research and } \\
\text { Management } \\
\text { Science (OR/MS) }\end{array}$} & Management Science (MS) & 4 \\
\hline 12 & & European Journal of Operational Research (EJOR) & 3 \\
\hline 13 & & Naval Research Logistics (NRL) & 3 \\
\hline 14 & & Omega: The International Journal of Management Science (OMEGA) & 3 \\
\hline 15 & & Decision Sciences (DS) & 3 \\
\hline
\end{tabular}

Table 1: Identified data sources ( ${ }^{\star} A B S$ ranking as on 17 Nov. 2010)

The keywords or search strings used for filtering the raw data from these data sources were constructed as "risk", "disruption", "vulnerability" and "uncertainty". These search strings were identified based on the authors previous understanding of the SCRM field and was also supported with several discussions with experts consisting of academicians and practitioners within the field of supply chain risks both in the UK and across the globe. Some of the academicians are members of the 'International Supply Chain Risk Management Network'.

Risk management within organisations is not a new phenomenon and it is also a prevalent theme within the Finance and IT industry. However, we believe that risk management within supply chains gathered more focus and momentum only after the 9/11 attacks in the US. It was observed during a preliminary search that, significant number of researchers started researching on SCRM in early 2000. In order to restrict the scope of the literature survey, we decided to analyse articles published only in the one decade (from 2000 to 2010). It was also observed that the research focus was initially profound for US and UK academics, hence the significance of the journals in which these papers were published in. Global recession affecting supply chains in 2001-02 (Hilmola et al., 2005) and challenges in outsourcing seem to have given a sound platform for research on supply chain risks in the early part of the decade. The preliminary search using search strings within 15 identified international journals found a significant number of articles. Filtering this data further and considering only publication dates between 2000 to 2010 yielded 140 quality articles. 
A. Ghadge, S. Dani and R. Kalawsky (2012), Supply Chain Risk Management: Present and Future Scope, International Journal of Logistics Management, Vol. 23 No. 3, pp. 313-339.

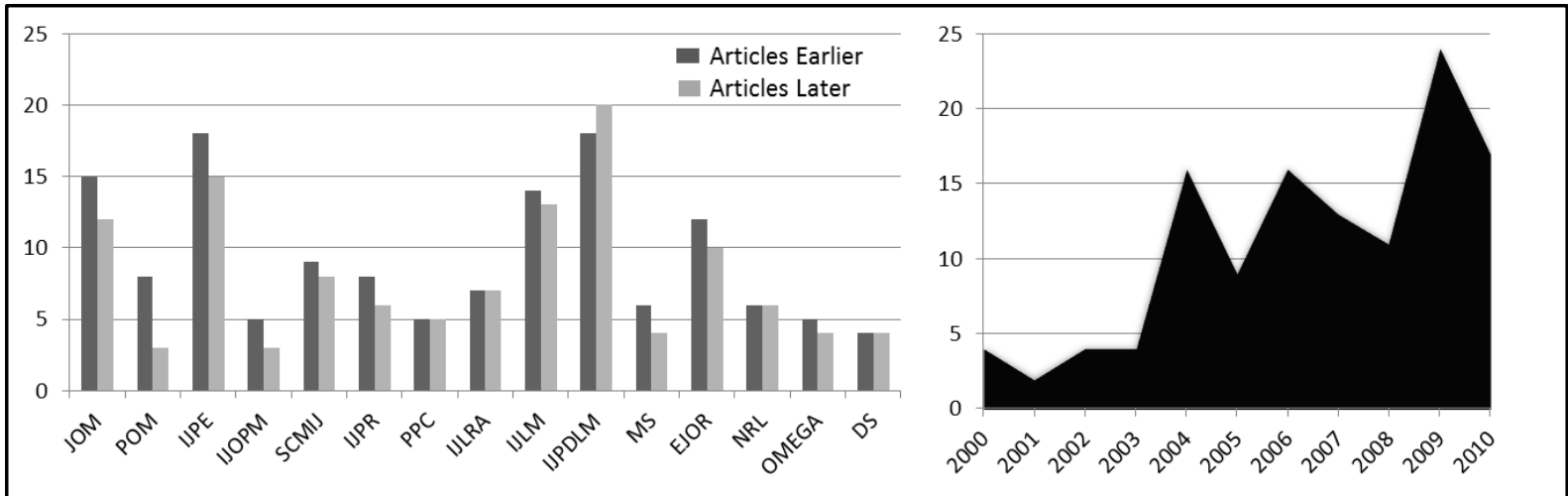

Figure 2: Journal-wise and year-wise distribution of articles

We further refined this search by setting exclusion criteria for the articles discussing risk management in other interdisciplinary fields like Finance, Enterprise, Information Technology, etc. In order to improve the quality of research we finally selected 120 quality articles by manual selection. Knowledge management techniques were used to document these individually and independently selected articles for SLR. This database of 120 articles was critically analysed by manual and statistical techniques. Knowledge discovery through text mining was used to validate these manual and statistical findings.

\section{DATA SCREENING, EXTRACTION AND SYNTHESIS}

During the first stage of the manual screening of the database, it was found that there was a radical increase in number of articles published in the field of SCRM from year 2004 (Figure 2). Preliminary studies showed that, the traditional focus of supply chains looking at operational risks shifted towards more tactical and strategic risks due to an increase in global outsourcing activities. The 9/11 terrorist attack (2001) disrupted major supply chains in the early part of the decade and also triggered interest in the SCRM field (Chopra and Sodhi, 2004; Sheffi, 2005). Although 2001 was the year of the 9/11 strikes we believe that the increase in the number of articles on SCRM during 2003 and 2004 were the result of the publishing timelines since active research started in the late 2001. The year 2009 represented a promising year in SCRM research contributing the most in the volume of papers published. Descriptive analysis of keywords and countries contributing to SCRM showed that the US academics contributed the most SCRM articles. This is followed by UK as a single country contributor. This is believed to be driven by the fact that countries like USA, UK along with other European countries outsource the most and are more vulnerable to risks or disruptions. This is assumed to drive the interest of researchers from these countries. Although the specific research area was favoured by researchers from these countries in the initial years of the decade, SCRM as a research area grew rapidly within researchers in the China and South East Asia. Although the journals from these countries do not feature in this analysis on account of the filtering criteria and the focus on ABS listed journals, the academics from these countries feature in the papers that were selected for this analysis. Some of the cases considered in the papers have affiliation to companies within China and South East Asia.

QDA Miner ${ }^{\odot}$, a qualitative data analysis software developed by Provalis Research was used as a text mining platform to facilitate the systematic literature review process. The term 'Risk' was found to be mainly referred to the organizational and network related disturbances whereas disruption is commonly referred to exposure to environmental (man-made and natural) disturbances. Figure 3 depicts the frequency of keywords which signifies the importance of a word or phrase in a research area. Identifying these keywords and phrases through text mining provided the confidence in using the initially identified search strings. Using TF-IDF (Term Frequency-Inverse Document Frequency) weight search criteria in text mining, the frequently used keywords and phrases were identified. TF-IDF weight measures the relevance of a specific word as a statistical measure. This is commonly used to weight information retrieval in data mining techniques. The similarity in used search strings and keywords identified by text mining provided the required confidence in the data screening process. Risk, disruption, uncertainty, vulnerability and security were found to be most commonly used keywords in most number of cases (articles). Similarly, keywords like outsourcing, resilience, contract and simulation represents a strong association with the SCRM field. The phrases identified as seen in 
A. Ghadge, S. Dani and R. Kalawsky (2012), Supply Chain Risk Management: Present and Future Scope, International Journal of Logistics Management, Vol. 23 No. 3, pp. 313-339.

Figure 3 reflects important links between information sharing, internal integration and risk behaviours in SCRM.

\begin{tabular}{|c|c|c|c|c|c|c|c|c|c|c|c|c|c|c|c|}
\hline & FREQUENCY & \% SHOWN & \% PROCESSED & \% TOTAL & NO. CASES & $\%$ CASES & $T F \cdot I D F$ & & FREQUENCY & \% SHOWN & $\%$ PROCESSED & \% TOTAL & NO. CASES & $\%$ CASES & TF $\cdot$ IDF \\
\hline SUPPLY & 11581 & $4.7 \%$ & $2.4 \%$ & $1.2 \%$ & 101 & $84.2 \%$ & 867.0 & OPERATIONS_MANAGEMENT & 409 & $6.8 \%$ & $0.1 \%$ & $0.0 \%$ & 54 & $45.0 \%$ & 141.8 \\
\hline RISK & 8435 & $3.4 \%$ & $1.8 \%$ & $0.9 \%$ & 105 & $87.5 \%$ & 489.2 & SUPPLY_RISK & 462 & $7.7 \%$ & $0.1 \%$ & $0.1 \%$ & 61 & $50.8 \%$ & 135.8 \\
\hline CHAIN & 8134 & $3.3 \%$ & $1.7 \%$ & $0.8 \%$ & 102 & $85.0 \%$ & 574.1 & RISK_AVERSE & 139 & $2.3 \%$ & $0.0 \%$ & $0.0 \%$ & 15 & $12.5 \%$ & 125.5 \\
\hline MANAGEMENT & 6157 & $2.5 \%$ & $1.3 \%$ & $0.6 \%$ & 108 & $90.0 \%$ & 281.7 & RISK_NEUTRAL & 119 & $2.0 \%$ & $0.0 \%$ & $0.0 \%$ & 13 & $10.8 \%$ & 114.9 \\
\hline SUPPLIER & 2417 & $1.0 \%$ & $0.5 \%$ & $0.2 \%$ & 93 & $77.5 \%$ & 267.6 & STRATEGIC VULNERABILITY & 62 & $1.0 \%$ & $0.0 \%$ & $0.0 \%$ & 2 & $1.7 \%$ & 110.2 \\
\hline RISKS & 2245 & $0.9 \%$ & $0.5 \%$ & $0.2 \%$ & 85 & $708 \%$ & 3362 & LOGISTICS_MANAGEMENT & 333 & $5.6 \%$ & $0.1 \%$ & $0.0 \%$ & 57 & $47.5 \%$ & 107.7 \\
\hline SUPPLIERS & 1754 & $0.7 \%$ & $0.4 \%$ & $0.2 \%$ & 83 & $69.2 \%$ & $\begin{array}{r}300.2 \\
280.8\end{array}$ & SUPPLY_RISK_MANAGEMENT & 269 & $4.5 \%$ & $0.1 \%$ & $0.0 \%$ & 48 & $40.0 \%$ & 107.0 \\
\hline MODEL & 1719 & $0.7 \%$ & $0.4 \%$ & $0.2 \%$ & 95 & $79.2 \%$ & 174.4 & SUPPLY_CHAINS & 638 & $10.6 \%$ & $0.2 \%$ & $0.1 \%$ & 82 & $68.3 \%$ & 105.5 \\
\hline INFORMATION & 1715 & $0.7 \%$ & $0.4 \%$ & $0.2 \%$ & 94 & $78.3 \%$ & $\begin{array}{l}14.4 \\
181.9\end{array}$ & $\begin{array}{l}\text { RISK_MANAGEMENT } \\
\text { RELATIONAL_RISK }\end{array}$ & $\begin{array}{r}417 \\
56\end{array}$ & $\begin{array}{l}7.0 \% \\
0.9 \%\end{array}$ & $\begin{array}{l}0.1 \% \\
0.0 \%\end{array}$ & $\begin{array}{l}0.0 \% \\
0.0 \%\end{array}$ & $\begin{array}{l}69 \\
2\end{array}$ & $\begin{array}{l}57.5 \% \\
17 \%\end{array}$ & $\begin{array}{l}100.2 \\
996\end{array}$ \\
\hline BUSINESS & 1621 & $0.7 \%$ & $0.3 \%$ & $0.2 \%$ & 101 & $84.2 \%$ & 121.3 & INFORMATION_SHARING & $\begin{array}{r}96 \\
141\end{array}$ & $2.4 \%$ & $0.0 \%$ & $0.0 \%$ & 24 & $20.0 \%$ & $\begin{array}{l}99.6 \\
98.6\end{array}$ \\
\hline PROCESS & 1616 & $0.7 \%$ & $0.3 \%$ & $0.2 \%$ & 94 & $78.3 \%$ & 171.4 & SUPPLY_DISRUPTION_RISK & 75 & $1.3 \%$ & $0.0 \%$ & $0.0 \%$ & 6 & $5.0 \%$ & 97.6 \\
\hline PRODUCT & 1554 & $0.6 \%$ & $0.3 \%$ & $0.2 \%$ & 94 & $78.3 \%$ & 164.8 & SUPPLY_BASE & 117 & $2.0 \%$ & $0.0 \%$ & $0.0 \%$ & 18 & $15.0 \%$ & 96.4 \\
\hline DEMAND & 1528 & $0.6 \%$ & $0.3 \%$ & $0.2 \%$ & 93 & $77.5 \%$ & 169.1 & SUPPLY_MANAGEMENT & 584 & $9.7 \%$ & $0.2 \%$ & $0.1 \%$ & 83 & $69.2 \%$ & 93.5 \\
\hline PRODUCTION & 1485 & $0.6 \%$ & $0.3 \%$ & $0.1 \%$ & 100 & $83.3 \%$ & 117.6 & WHOLESALE_PRICE & 85 & $1.4 \%$ & $0.0 \%$ & $0.0 \%$ & 10 & $8.3 \%$ & 91.7 \\
\hline LOGISTICS & 1446 & $0.6 \%$ & $0.3 \%$ & $0.1 \%$ & 85 & $70.8 \%$ & 216.6 & INTERNAL_INTEGRATION & 49 & $0.8 \%$ & $0.0 \%$ & $0.0 \%$ & 2 & $1.7 \%$ & 87.1 \\
\hline
\end{tabular}

Figure 3: Keywords and phrases identified through Text Mining

Data synthesis was done using various predetermined criteria for developing the family of classifications. Predetermined criteria were identified from various SCRM aspects. Clustering is a useful technique in text mining for discovering interesting data distribution and patterns from unorganized data (Ponsporrata et al., 2007). Initial concept mapping for classification was verified through Dendrogram, a text mining technique for concept mapping. Hierarchical clustering algorithms built within the software produce a nested sequence of partitions. These associations and partitions forming the groups are represented in a tree like structure called as 'Dendrogram'. The Dendrogram provides a visual representation of data correlation. Each Dendrogram node is formed by an association of two or more keywords forming branches and each branch length represents functional diversity in clusters. Figure 4 and, 5 shows an example of cluster diagramming and concept mapping for SCRM. The cluster diagram in figure 5 shows that the holistic approach to SCRM is evidently lacking as the link between the core cluster and outer elements is missing from the literature. We define 'holistic' as the process which considers the whole system and also the interdependence between its individual components. Elements like behavioural dimension of risks, risk sensitivity and real options shown associated in the cluster are clearly missing the links within the broad domain of SCRM. The strength of clustering is specified by the level as well as length at which elements joins a cluster (Anderberg, 1973). Each cluster expands into a larger concept map providing further detailed insights. The identified keywords, phrases, frequencies, classifications, clusters using text mining provide the necessary support for data extraction and synthesis stage in SLR.

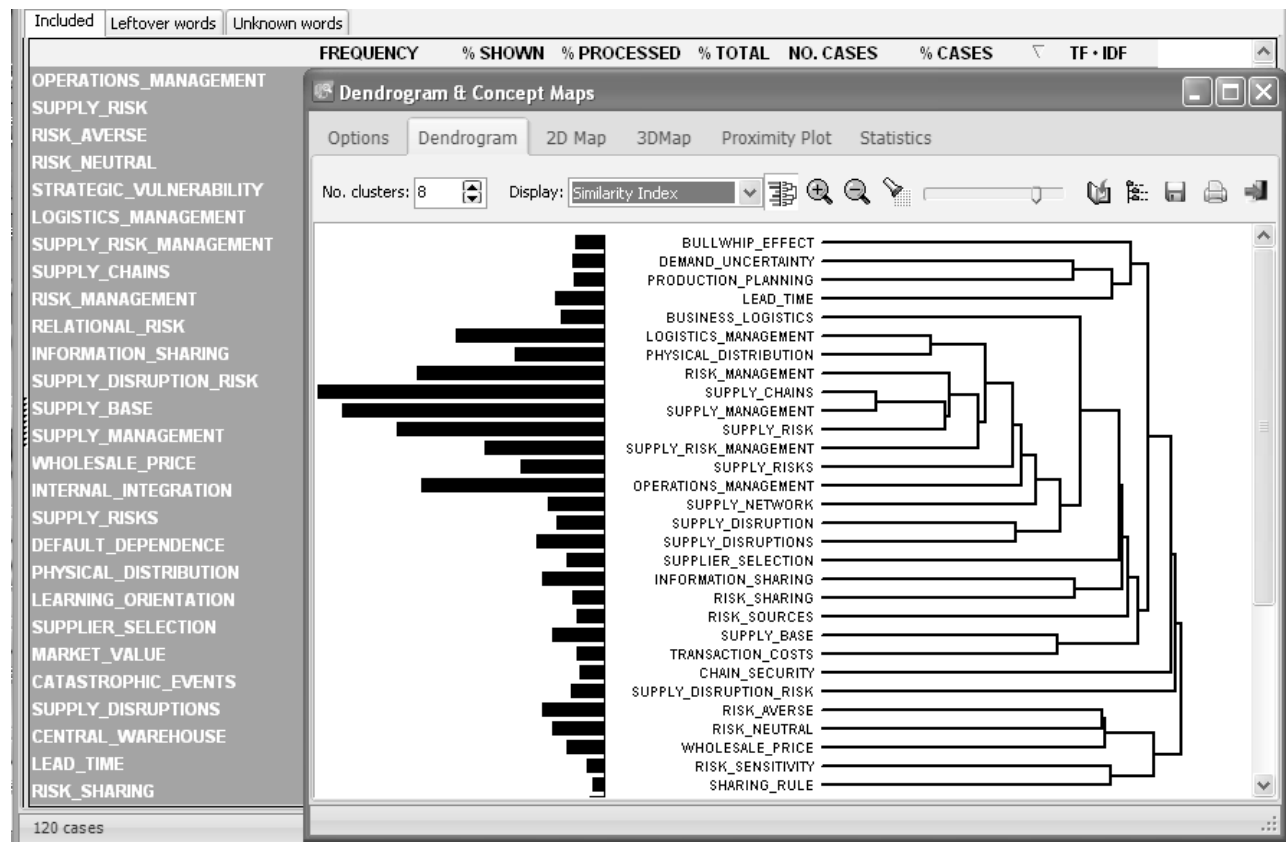

Figure 4: Concept mapping using Dendrogram for classification 
A. Ghadge, S. Dani and R. Kalawsky (2012), Supply Chain Risk Management: Present and Future Scope, International Journal of Logistics Management, Vol. 23 No. 3, pp. 313-339.

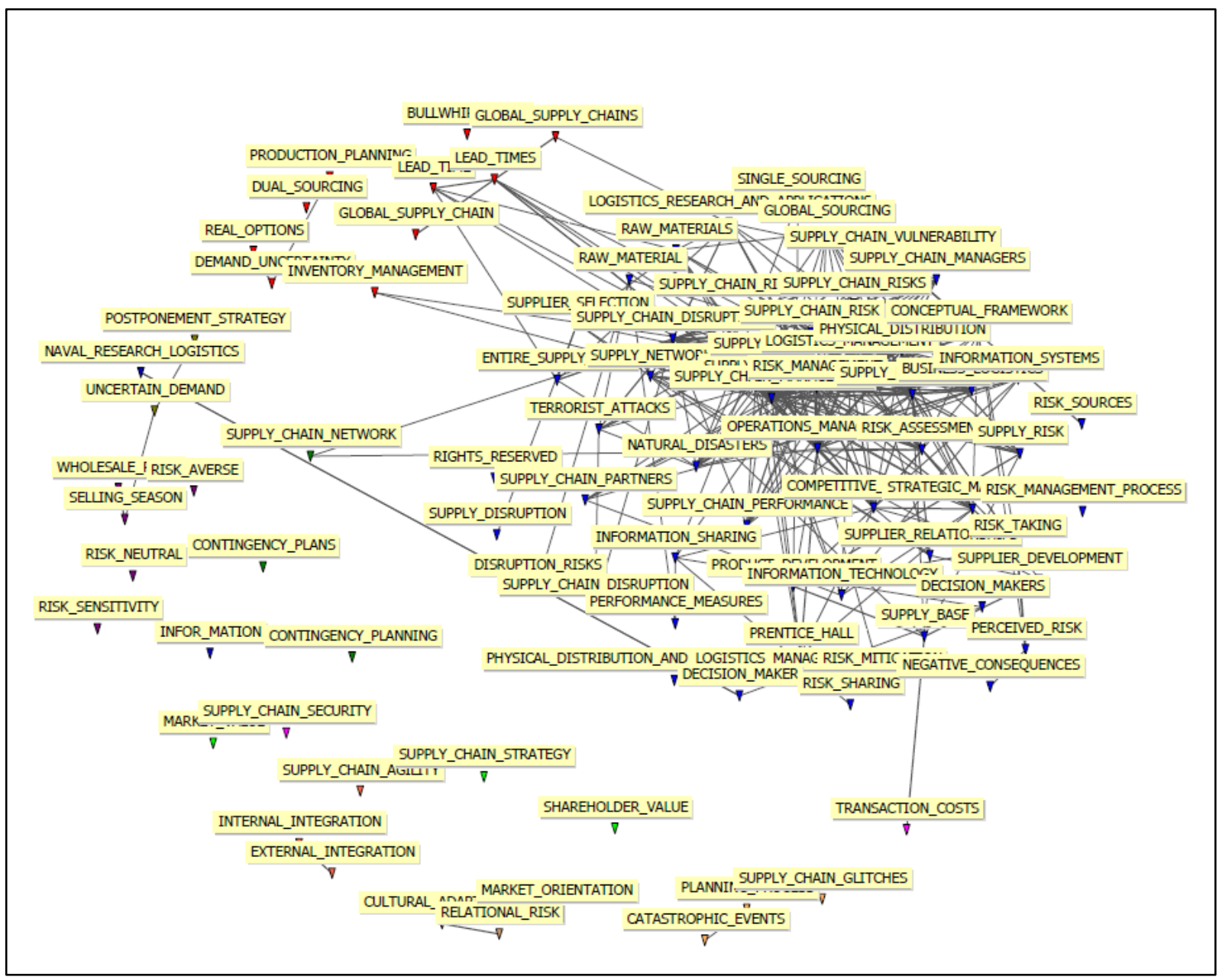

Figure 5: SCRM Cluster Diagram

The developed typologies were identified based on clustering patterns, researcher's understanding and SCRM expert's perception of the field. Following typologies were identified for the data screening:

1. Based on type of risk: There is diversity in classifying risks in SCRM (Dani and Deep, 2010; Ghadge et al., 2010), this demanded clear and distinct classification for the data analysis. We followed the classification provided by Juttner et al. (2003) based on sources of risk as Organizational risk, Network Risk and Other risks comprising of environmental (man-made and natural disasters), political/Social and exchange rate risks.

2. Based on Management level: Mitigation strategies are decided based on expected level of management. It could be Operational, Tactical or Strategic depending on the nature of problem and requirement.

3. Based on research methodology: Qualitative and Quantitative research methodologies are classified to understand tools and techniques used in SCRM.

4. Based on risk management process: Based on the perception of researchers in SCRM, the risk management process is generally classified as risk identification, assessment and mitigation and/or control.

5. Based on approach to SCRM: The risk mitigation approach could be either proactive or reactive. This is done to identify mitigation strategies commonly used in the field of SCRM.

Two other classifications based on publication period and research contributing country were not considered as significantly important for this research due to its independent nature, the academic publication process and non-association with the actual SCRM research. 
A. Ghadge, S. Dani and R. Kalawsky (2012), Supply Chain Risk Management: Present and Future Scope, International Journal of Logistics Management, Vol. 23 No. 3, pp. 313-339.

\section{DATA ANALYSIS}

\section{Descriptive analysis}

Although 'publication period' and 'contributing country' is not considered under the thematic analysis, it is useful to have an overview using descriptive analysis. With reference to table 2, the statistical analysis of the data depicts that nearly half $(46.66 \%)$ of the contributions were from the USA. 'International' is used to indicate collaborative research among co-authors representing more than two countries (Altay and Green, 2006) and is considered separately in the table. Other leading countries researching SCRM and showing keen interest in supply chain disruptions are UK, Sweden, China, Canada and Italy. It is observed that research contributions from UK researchers are published mostly in the OM area and qualitative in nature. The methodological aspects of SCRM research are considered under thematic analysis. Dividing the decade into two halves showed a distinctive progress of SCRM research. Publications on SCRM in the later part of decade have almost doubled as shown in Table 2. This clearly shows the potential of SCRM research in current dynamic world.

\begin{tabular}{|c|c|c|c|c|c|c|c|}
\hline Typology type & $\begin{array}{c}\text { All } \\
\text { Journals }\end{array}$ & $\begin{array}{c}\text { OM } \\
\text { Journals }\end{array}$ & $\begin{array}{l}\text { OR/MS } \\
\text { Journals }\end{array}$ & Typology type & $\begin{array}{c}\text { All } \\
\text { Journals }\end{array}$ & $\begin{array}{c}\text { OM } \\
\text { Journals }\end{array}$ & $\begin{array}{c}\text { OR/MS } \\
\text { Journals }\end{array}$ \\
\hline \multicolumn{8}{|l|}{ Contributing } \\
\hline country & $\%$ & $\%$ & $\%$ & Research approach & $\%$ & $\%$ & $\%$ \\
\hline USA & 46.66 & 43.47 & 57.14 & Qualitative & 54.16 & 67.39 & 10.71 \\
\hline UK & 15.83 & 20.65 & 0.00 & Quantitative & 36.66 & 23.91 & 78.57 \\
\hline International & 16.66 & 11.95 & 32.14 & Mixed & 9.16 & 8.69 & 10.71 \\
\hline \multirow{2}{*}{ Other countries } & 21.66 & 25.00 & 10.71 & & & & \\
\hline & & & & $\begin{array}{l}\text { Risk management } \\
\text { process }\end{array}$ & & & \\
\hline Publication period & & & & Identification & 35.00 & 32.39 & 5.89 \\
\hline $2000-2005$ & 32.50 & 35.86 & 78.57 & Assessment & 14.33 & 16.64 & 78.14 \\
\hline $2006-2010$ & 67.50 & 64.13 & 21.42 & $\begin{array}{l}\text { Mitigation/Control } \\
\text { Holistic }\end{array}$ & $\begin{array}{c}5.83 \\
44.16\end{array}$ & $\begin{array}{c}4.72 \\
46.47\end{array}$ & $\begin{array}{c}13.84 \\
2.85\end{array}$ \\
\hline \multicolumn{8}{|l|}{ Type of Risk } \\
\hline Organizational & 4.85 & 5.87 & 0.00 & Risk mitigation approach & & & \\
\hline Network & 48.78 & 52.69 & 11.65 & Proactive & 56.33 & 41.60 & 60.71 \\
\hline Other & 14.63 & 12.38 & 50.61 & Reactive & 23.33 & 13.91 & 18.42 \\
\hline Holistic & 31.66 & 28.58 & 38.42 & Holistic & 20.83 & 44.92 & 21.07 \\
\hline
\end{tabular}

Table 2: Analysis of SCRM

\section{Thematic analysis}

Table 2 also depicts a detailed analysis of other important typologies that provide an interpretative analysis of the SCRM field. The classification schematic for the systematic analysis of SCRM literature was based on the typology as identified in the previous section. Risk classification, research methodology and risk management process typologies are further systematically analysed following the thematic analysis approach.

Risk classification: Supply chain risks were broadly identified as organizational, network and other risks comprising of natural and man-made disasters. We grouped these risks based on similarity and the interdependent nature of risks.

Organizational Risks: Organizational risks commonly comprise of inventory risk, process/operational risk, quality risk and management risk. Inventory risk is a risk arising from buffer or stock out inventories leading to unnecessary handling cost or lost opportunity cost (Cachon, 2004; Juttner et al., 2003; Childerhouse et al., 2003; Zsidisin, 2003a; Chopra and Sodhi, 2004). Inventory risk could be mitigated by reducing cash-to-cash cycle and improved forecasting techniques (Papadakis 2006). Process or operational risk can be defined as risks initiated with operational events disrupting material or information flow within supply chain (Lockamy et al., 2010, Christopher and Peck, 2004; Jiang et al., 2007; Lewis, 2003; Cavinato, 2004; Colicchia et al., 2010; Cigolini and Rossi, 2010). Quality risk may result from problems at plant or due to supplier failure. Researchers identify outsourcing activity as being responsible for product quality risk (e.g. Zsidisin et al., 2000; Zsidisin et al., 2004; Chopra and Sodhi, 2004; Kaya, 2008) but this may be associated closely with a network risk than an organizational risk. Management risk is type of risk that arises from poor management ability 
A. Ghadge, S. Dani and R. Kalawsky (2012), Supply Chain Risk Management: Present and Future Scope, International Journal of Logistics Management, Vol. 23 No. 3, pp. 313-339.

to anticipate and react to the market demands. The SCRM literature is lacking in identifying management risk as a critical risk for any business success.

Network Risks: Network related risks arise from interactions between organisations within the supply chain network (Juttner et al., 2003). Supply risk, supplier default and demand risk are some of the prominent network related risks being most researched in SCRM field (48.78\%) for its apparent reasons of being "extrinsic" in nature. Supply risk, according to Zsidisin et al. (2004) is the potential occurrence of an incident associated with the inbound supply leading to inability of the purchasing organization to meet customer demand. Supply risk was one of the risks most discussed and researched in the literature. Wu et al. (2007) provides an integrated approach to classify, manage and assess supply risks. Supply chain disruption due to supplier default risk has been widely neglected (Wagner et al., 2009) and this is also confirmed from observations made through SLR. Demand risks are the risks associated with demand uncertainty (Tang and Tomlin, 2008) or risk associated with the outbound logistics flow (Svensson, 2002).

Environmental Risks: Environmental risks are defined as events driven by external forces such as weather, earthquakes, political, regulatory and market forces (Wagner and Bode, 2006). Recent research has shown an increased attention towards environmental (man-made and natural) disruptions due to several global events in past disrupting supply chains. Environmental risk sources comprise any uncertainties arising from the supply chain environment interactions (Juttner et al., 2003). Environmental risk can arise due to physical, social, political, legal or economic environment (Bogataj and Bogataj, 2007).

PROACTIVE RISK MITIGATION STRATEGY

- Supplier development/management: Risk sharing through contract manufacturing, contractual governance, Dual/multi sourcing.

- Supply chain Contracts: Developing incentive contracts, Mix and volume flexibility contracts for risk mutual benefits, VMl/buffer stock.

- Product/process Management: Product variety, postponement, product design and delivery management.

- Supplier relationship: Supplier collaboration through improved confidence, cultural adaptation, Continuous coordination.

\section{REACTIVE RISK MITIGATION STRATEGY}

- Contingency planning: strategic event management plan, enhanced flexibility in options.

- Disaster management: Robust recovery, Rebuilding of Supply chain, resource utilization/management, Scenario analysis for future disruptions.

- Demand management: Operational Rerouting, shifting customer demand, dynamic pricing.

\section{Table 3: Risk mitigation strategies in SCRM}

Risk management process: By analysing the data based on different risk management processes, most of the articles were found to be focused on risk identification activity (35\%). This depicts the embryonic stage of researchers in SCRM. Less attention is found to be given for holistic risk management processes. Only half of the articles analysed in the SLR discussed about either implementing proactive or reactive risk mitigation strategies (61 out of 120). The general approach of researchers to risk mitigation is preferred to be proactive $(58.33 \%)$ as compared to being reactive $(23.33 \%)$. But from practitioner's perspective, it is difficult to justify the investment in proactive risk mitigating strategies (Dani, 2008).

Risk mitigation and control strategies discussed by researchers were classified into two approaches as proactive and reactive. For holistic risk mitigation; agility, flexibility and preparedness are preferred generic strategies (Ponomarov and Holcomb, 2009). Key proactive and reactive risk mitigating strategies discussed in the literature are compiled in Table 3. It is found that at a strategic level, contingency planning and risk sharing outsourcing contracts are prominently used as risk mitigation strategies. Use of multi-strategy approach such as combining supplier alliance network with lead time reduction and/or recovery planning system (Tang, 2006a) can be effective for mitigating situational disruptions.

Research Methodology: Data synthesis of research methodologies used for decision-making in SCRM field was broadly classified as qualitative and quantitative methods. From table 2 , it is evident that the preferred methodology has been qualitative.

Qualitative research methods were further divided based on research approaches as empirical study, conceptual theory and Literature survey. Similarly, Quantitative research methods were divided 
A. Ghadge, S. Dani and R. Kalawsky (2012), Supply Chain Risk Management: Present and Future Scope, International Journal of Logistics Management, Vol. 23 No. 3, pp. 313-339.

into mathematical modelling, statistics and probabilistic theory and Simulation for detailed thematic analysis.

Empirical study: Empirical research employs case study, industrial survey, structured/ informal interview and focus group methodologies for analysing information gained by means of observation or secondary data study.

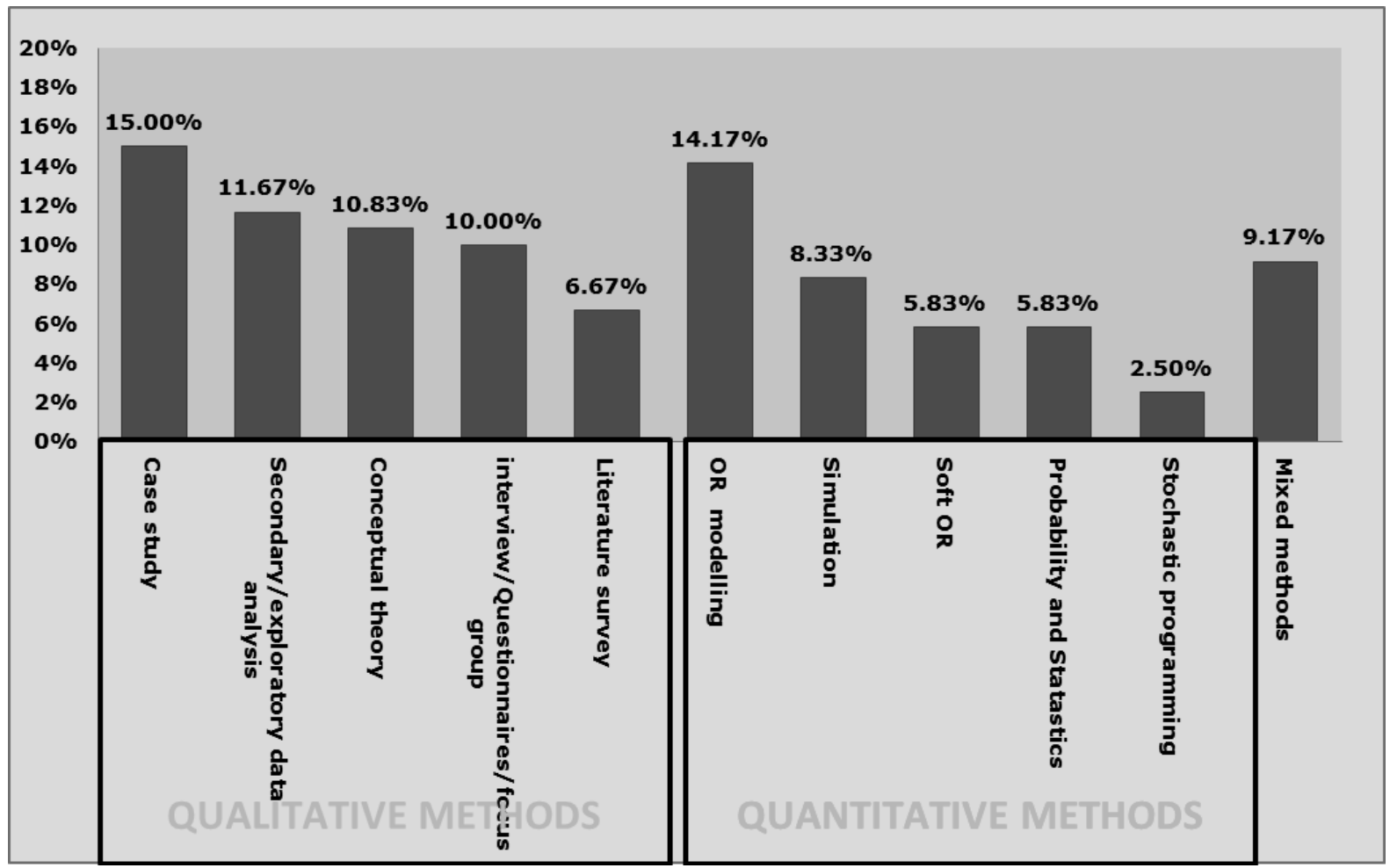

Figure 6: Preferred research methodologies in SCRM

Detailed analysis of data classified as Qualitative, Quantitative and mixed methods showed case study approach as being the most adopted by researchers for dealing with problems mainly at a strategic management level as seen in Figure 6. Apart from the preferred research methodologies categorised in Figure 6, the data analysis also shows the percentage use of each methodology within the context of SCRM research. A number of researchers have used the case study approach to study supply chain risks. These studies have looked at various topics and sectors; sources of uncertainty in the food sector (Vorst et al., 1998), strategies for global supply chain environments (Christopher and Peck, 2006; Khan et al., 2008), risks and mitigation best practices (Finch, 2004), knowledge management to manage risks (Hallikas et al., 2004), holistic nature of supply chain risks within the automotive and electronic industries (Mauricio et al., 2004). The analysis showed that $80 \%$ of case studies were focussed on network related risks. In qualitative research methods; other prominently used tools were exploratory analysis of secondary data using industrial surveys, Conceptual theory building for developing frameworks and use of Interviews/Questionnaires/Focus group study. Jonsson (2000) utilised surveys to study disruption whereas Blackhurst et al. (2005) using a multi-methodology empirical study identifies a critical need for quantitative assessment tools that could identify high probability nodes for disruptions within supply chain. Craighead et al. (2007) employed a three-phase empirical study of case study, interviews and focus group to study the severity of supply chain disruptions. Questionnaires and interviews are usually combined in qualitative research. Such combined qualitative approach was found to be effectively used for SCRM research in the past (e.g. Lewis, 2003; Jiang et al., 2009; Mantel et al., 2006; Brun et al., 2006; Autry and Bobbitt, 2008; Perry, 2007).

Conceptual model/theory: 'Conceptual' is meant to represent a research methodology describing fundamental concepts on SCRM (Vanany et al., 2009). Due to the developing stage of the SCRM field, conceptual theory or framework development are frequently attempted by many SCRM researchers. Svensson $(2000,2002)$ conceptualizes the inbound and outbound vulnerability in supply chain based on sources and categories of disturbances. Similarly, other conceptual frameworks like 
A. Ghadge, S. Dani and R. Kalawsky (2012), Supply Chain Risk Management: Present and Future Scope, International Journal of Logistics Management, Vol. 23 No. 3, pp. 313-339.

supply chain security orientation framework (Autry and Bobbit, 2008), supplier risk management framework (Matook et al., 2009), model for SC network risk (Trkman and McCormack, 2009), risk and performance framework for SCRM (Ritchie and Brindley, 2007), disaster recovery pyramid (Richey Jr., 2009), SC: interactive adaptive system (Peck, 2005; Peck, 2006), SC disruption risk management (Kleindorfer and Saad, 2005), reactionary risk mitigation model (Dani and Deep, 2010) were found to be used for further research developments in SCRM.

Literature survey: Literature review is fundamental for any research field. Literature survey in SCRM has been conducted by few researchers with help of academic peer-reviewed journals to draw interesting insights. List of all past literature surveys with their adopted research methodologies and key findings/contributions is presented in Table 4. Most of the literature surveys are found to be narrative in nature.

\begin{tabular}{|c|c|c|}
\hline AUTHOR(S) & RESEARCH METHODOLOGY & KEY FINDINGS/CONTRIBUTIONS \\
\hline $\begin{array}{l}\text { Juttner et al. } \\
\text { (2003) }\end{array}$ & $\begin{array}{l}\text { Literature survey findings are } \\
\text { compared with results from } \\
\text { exploratory semi-structured } \\
\text { interviews, focus groups are } \\
\text { undertaken to discover practitioners' } \\
\text { perceptions. }\end{array}$ & $\begin{array}{l}\text { Used four basic constructs to develop the concept: 1) } \\
\text { Sources of risk, 2) Adverse consequences of risk, 3) } \\
\text { Drivers of risk and 4) Mitigation strategies. } \\
\text { ldentified normative issues for future research in SCRM } \\
\text { focusing need of empirically grounded research. }\end{array}$ \\
\hline $\begin{array}{l}\text { Khan and Burnes } \\
\text { (2007) }\end{array}$ & $\begin{array}{l}\text { Literature review of broad literature } \\
\text { on risk and precise literature on } \\
\text { supply chain risk. }\end{array}$ & $\begin{array}{l}\text { Emphasize on the need to devise a robust and well- } \\
\text { grounded models. In-depth empirical research is } \\
\text { needed to identify adaptable tools in managing supply } \\
\text { chain risk by incorporate risk management tools and } \\
\text { techniques from other disciplines of research. }\end{array}$ \\
\hline $\begin{array}{l}\text { Williams et al. } \\
(2008)\end{array}$ & $\begin{array}{l}\text { Through review of the literature on } \\
\text { supply chain security (SCS) from } \\
\text { academic publications, white } \\
\text { papers, and practitioner periodicals. }\end{array}$ & $\begin{array}{l}\text { Provides good empirical findings and theory building } \\
\text { through categorization of literature on SCS. Quantitative } \\
\text { assessments are needed to better understand of SCRM. } \\
\text { SCS can lead to improved organizational performance. }\end{array}$ \\
\hline $\begin{array}{l}\text { Vanany et al. } \\
\text { (2009) }\end{array}$ & $\begin{array}{l}\text { Through review of journal } \\
\text { publications from } 2000-2007 \text { with } \\
\text { help of classifications into several } \\
\text { typologies. }\end{array}$ & $\begin{array}{l}\text { RFID and ERP will become important part of SCRM. Use } \\
\text { of IT for visibility, collaborative risk management } \\
\text { strategies for making supply chains robust is lacking. }\end{array}$ \\
\hline $\begin{array}{l}\text { Natarajarathinam et } \\
\text { al. (2009) }\end{array}$ & $\begin{array}{l}\text { Review of academic peer-reviewed } \\
\text { journals and case publications in } \\
\text { supply chain management } \\
\text { literature. }\end{array}$ & $\begin{array}{l}\text { Much of the research is focused on external sources and } \\
\text { proactive approaches to crisis in supply chains. } \\
\text { Recovery planning and scales for crisis management } \\
\text { needs attention. }\end{array}$ \\
\hline $\begin{array}{l}\text { Rao and Goldsby } \\
\text { (2009) }\end{array}$ & $\begin{array}{l}\text { Review of the literature on supply } \\
\text { chain risk and synthesis of the } \\
\text { broader domain of risk } \\
\text { management. }\end{array}$ & $\begin{array}{l}\text { Provides a typology of risks classified broadly as } \\
\text { Environmental, Industry and Organizational risks based } \\
\text { on identified variables from systematic key research } \\
\text { findings in SCRM. SCRM is an area in need of further } \\
\text { substantive investigation. }\end{array}$ \\
\hline $\begin{array}{l}\text { Tang and Nurmaya } \\
\text { Musa }(2010)\end{array}$ & $\begin{array}{l}\text { Literature survey and citation/co } \\
\text { citation analysis using academic } \\
\text { database to disclose SCRM } \\
\text { development. }\end{array}$ & $\begin{array}{l}\text { Need of an integrated view of SCRM is growing strongly. } \\
\text { Requirement of analysis tools for proactively managing } \\
\text { risks. Use of quantitative modeling in risk management is } \\
\text { lacking and their lies a huge potential in developing } \\
\text { quantitative models to make hard decisions SCRM. }\end{array}$ \\
\hline
\end{tabular}

Table 4: Past literature reviews in SCRM: Research method and finding

Quantitative research methods are broadly classified into mathematical modelling, simulation and statistical testing for detailed thematic analysis.

Mathematical Modelling: OR modelling can be broadly classified into hard OR and soft OR techniques. Hard OR techniques roughly consists of linear programming, game theory, queuing theory, Markov process (Carter and Price, 2001). And soft OR comprises of SWOT/PEST analysis, viable systems model, Scenario planning, systems thinking, etc. Linear programming was used to manage demand/supply uncertainty related problems (e.g. Sodhi, 2005; Lai et al., 2009). Parametric linear programming approach for risk measurement (Bogataj and Bogataj 2007), Stochastic modelling for risk and profit optimization (Goh et al., 2007), mixed-integer modeling for the disaster recovery ((Noel) Bryson et al., 2002; Barbarosoglu et al., 2002), Dynamic programming for disruption 
management in production planning (Yang et al., 2005) are few noticeable OR modeling related articles identified from SLR as most influential in SCRM research. Soft OR decision support tool like Analytical Hierarchy/Network Process is capable of selecting most appropriate solution from set of solutions (Satty, 1990) and found to be a useful tool by researchers in SCRM. (e.g. Leopoulos and Kirytopoulos, 2004; Levary, 2007; Gaudenzi and Borghesi, 2006). Scenario planning (Dani and Deep, 2010) also has found potential for the strategic decision making in SCRM. Other soft OR approaches like viable systems model, systems thinking are finding its application in SCRM research.

Statistics and Probability theory: Statistics and Probability theory is another commonly used quantitative research tool efficiently used mainly for hypothesis testing. With the help of linear regression model, Hung and Ryu (2008) test the hypothesis for changing risk preferences in supply chain inventory decisions.

Simulation: Simulation modelling provides a systematic approach for understanding the relative and interactive impact of factors/parameters for different scenario settings. Simulation methods are not uncommon for assessing and modelling supply chain risks (Zsidisin et al., 2004). Several types of simulation modelling namely, Agent based simulation (e.g. Datta et al. 2007); Monte Carlo simulation (e.g. Ermoliev et al., 2000; Wagner et al., 2010) and Discrete-event simulation (e.g. Manuj et al., 2009) are few of the visible simulation related articles identified in SLR. Most of the simulation platforms are used for solving operational management level problems. Manuj et al. (2009) provides an exceptional eight-step development process for the design, evaluation and implementation of supply chain simulation models. In spite of few observed cases, supply chain literature lacks analytical research using simulation to investigate supply risk (Kull and Closs, 2008).

Mixed methods combining two research methodologies were also found in the review $(9.17 \%)$. Undoubtedly, there is huge potential in developing quantitative models to make hard decisions in SCRM (Tang and Musa, 2010). Research methods suitable for capturing holistic as well as dynamic behaviour of risks within supply chain networks were found to be clearly lacking in the study.

\section{FUTURE RESEARCH AGENDA}

SLR is needed to propose a future research agenda (Torgerson, 2003). The extensive analysis of the selected papers identified new directions in the SCRM field. Some of the identified research areas are mentioned below as future research agenda for research in SCRM:

\section{Behavioural perceptions in risk management:}

The decision to choose the right risk strategy is crucial and is found to be commonly dominated by the behavioural aspect of managers. Research on developing practices for unbiased or rational decision making is unexplored area in SCRM approach demands research. The managerial perceptions of risks (Zsidisin, 2003b; Sodhi et al, 2012) are critical for SCRM has been studied by few researchers. Figures 5 and 6 depict the distance of this topic from the core research area. Choosing the appropriate risk management strategy in terms of risk averse, risk neutral, risk sharing or risk taking (Vanany et al., 2009) behaviour will have a direct impact on the mitigation.

\section{Sustainability factors:}

It is inferred from this research that sustainability factors (economic, environmental and social) will have a larger influence on how supply chains are designed in the future. This also leads to an inference that noncompliance with sustainability factors could provide supply chains risks and disruptions. Risks derived from enhanced reverse logistics activities for remanufacturing and recycling of materials and new government legislations on supply chains will be an important area for future research. Hence, although companies are increasingly focused on remaining profitable, there is greater need to mitigate risks and implement sustainability practices.

\section{Risk mitigation through collaboration contracts:}

It was evident during the analysis that, supplier default risk, quality risk and management risk within SC network are underexplored. Collaboration and outsourcing by introducing risk sharing and/or contracts amongst supply chain partners can help to improve the network efficiency (Urciuoli, 2010). Development of supplier partnerships and strategic alliances is becoming a key element for long term profitability as well as a robust risk mitigation strategy. Contingency/recovery planning strategies needs to be industry or supply chain specific (Juttner et al, 2003). Most of the previous research has focussed on different SC contracts in the context of price and demand fluctuations (Wakolbinger and Cruz, 2011) but, long term contracts for disruption management are lacking in the literature. Risk 
A. Ghadge, S. Dani and R. Kalawsky (2012), Supply Chain Risk Management: Present and Future Scope, International Journal of Logistics Management, Vol. 23 No. 3, pp. 313-339.

sharing contracts have potential for handling risks in supply chains for network coordination in the future.

\section{Visibility and Traceability:}

Risk mitigation (proactive management or reactive risk response) can be greatly improved if information is readily available, is timely and accurate. Future Information and Communications Technologies (ICT) are expected to make a big impact in terms of visibility of the supply chain. Current technologies such as RFID, ERP and GPRS will become important information tools for management of supply chain risks (Tang, 2006b; Wilson, 2007; Rao and Goldsby, 2009; Vanany et al., 2009). The analysis depicts that visibility and traceability do not feature within the core of the research on SCRM. Hence, this will have an impact on the future work.

\section{Risk propagation and recovery planning:}

Research in disruption propagation, examining effects and recovery of the supply chain risks is lacking in the literature (Wu et al., 2007; Khan and Burnes, 2007; Natarajarathinam et al., 2009). Risk profile modelling and modelling of risk propagation in terms risk drivers like cost, duration, service will provide greater visibility for effective risk management. Understanding the risk potential beyond the dyad through the chain and then the network provides an insight into how risk can propagate. This has been evident in the recent past in the automotive industry as an effect of the Japanese Tsunami. Understanding risk propagation can also lead to better proactive risk management models.

There is a critical global need for recovery planning to mitigate against the effect of disasters ((Noel) Bryson, 2002). Uncertainties in the supply chain environment and also some instances of known risks provide instances when the only strategy available is to recover quickly after the risk has occurred. Creating the appropriate risk recovery models also needs proactive planning and a combination of the appropriate information and human intervention.

\section{Industry Impact:}

Although, this study is related to academic work on SCRM, it is vital to put it in the context of the impact that the work creates within industry. Although there may be a debate on which methodology is the most appropriate and whether quantitative models provide a better understanding and theory than qualitative work, it is the opinion of the authors that the research should have a direct influence on industry practices. Various authors have suggested the requirement for better risk management. Some of the proponents have suggested the following for better research in SCRM; empirically grounded research (Juttner et al., 2003), Quantitative tools like mathematical programming models, simulation models (Rao and Goldsby, 2009), Analytical/Network Hierarchy Process (Vanany et al., 2009), complexity and graph theory (Colicchia and Strozzi, 2012), development of well-grounded models by considering other interdisciplinary research approaches (Khan and Burnes, 2007).

\section{Holistic approach to supply chain risk management:}

Holistic supply chain risk management is found to be lacking in current literature and systems approach has the potential to guide in that direction. Mingers and White (2010) suggest that a system of systems approach is expected to bring fresh thinking for existing problems and to further uncertain world. An integrated approach to SCRM needs to incorporate the risk issues from industry practice (Tang and Musa, 2010). Research on redesigning SC strategies is a fertile area in current global, uncertain and dynamic environment. To the best of our knowledge no paper exists which relates product life cycle to SCRM. Quality risks like vehicle recalls, poor customer service are regular and primarily associated with the design and development aspects in the product lifecycle management. The multidimensional perspective focussing on management processes, risk dimensions, impact flows and mitigation alternatives needs to be studied in whole. It is our opinion that perceiving the supply chain as a system with multiple stakeholders and multiple interactions and then using systems thinking to understand the risk challenges is a largely unexplored area and has future scope.

Figure 7, presents an overview of the future scope. The linkages between the various factors depict the relationships and the flow of the work. The figure presents a map for future academic challenges. This is a macro representation and we hope that other researchers will be able to take this schematic to consider the detailed challenges within each factor. However, it is our opinion that the macro linkages will still hold ground. 
A. Ghadge, S. Dani and R. Kalawsky (2012), Supply Chain Risk Management: Present and Future Scope, International Journal of Logistics Management, Vol. 23 No. 3, pp. 313-339.

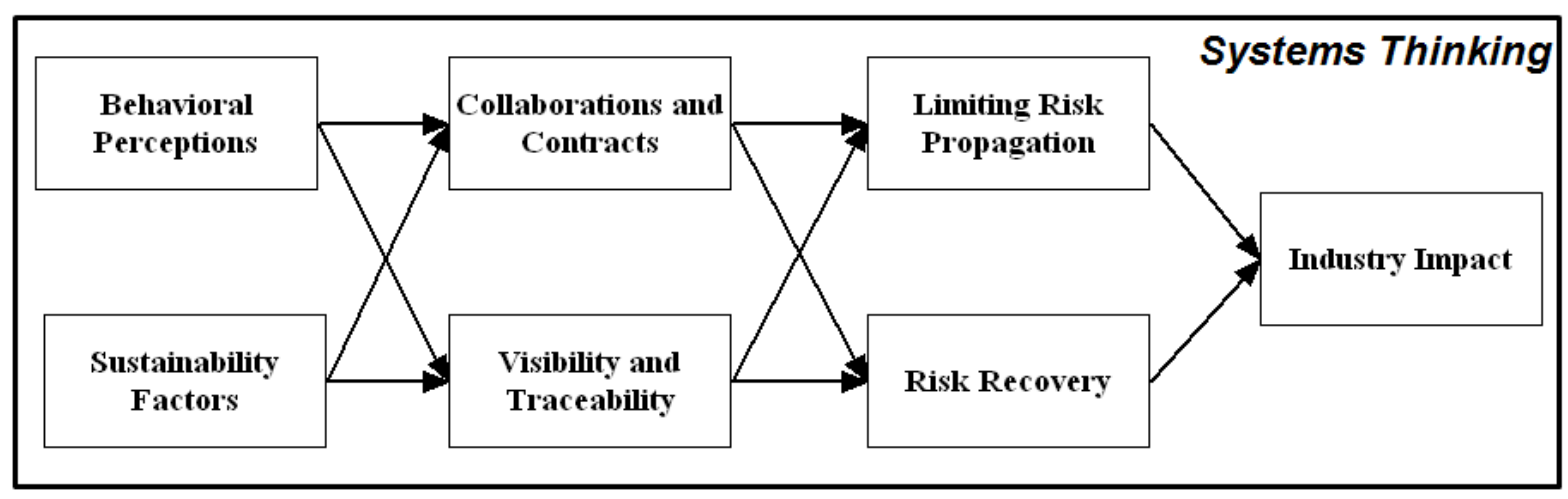

Figure 7: Overview of the future research scope for SCRM

Figure 7 depicts two major research strands representing the causal linkages between the future factors. The two strands start at 'Behavioural Perceptions' and 'Sustainability Factors'. Although a causal link between these two factors is also possible, it is not considered within this research as it can form an independent scope for future research. In the first strand, it is proposed that the perceptions of those involved in managing supply chain risks will have an impact on how collaboration agreements between supply chain partners are formed and the types of contracts which will be formulated. 'Risk taking' or 'being risk averse' will affect the systems being employed for creating visibility and traceability in the chain. There is a hidden implication (although not shown) that the choice of systems for visibility and traceability will also have an effect on the collaboration and contractual agreement and vice versa. The figure then proposes that both the "collaboration and contractual agreements' and 'the visibility and traceability' systems will have an impact on how supply chain risk propagation is contained and what processes are employed for supply chain recovery. It is important that academics should consider the appropriate methodologies when researching supply chain risk to bring into context the industrial challenges and hence the research expects a direct influence on industry practices. The selection of research design (whether qualitative or quantitative) should not restrict the ability of the research to create the necessary industry impact. The second strand, starts at 'Sustainability Factors' and it is proposed that non-compliance of supply chain sustainability factors may become a source for risks. Hence, sustainability factors will influence collaboration agreements and supply chain contracts. The requirement to meet environmental and social (ethical) criteria will also affect the types of systems chosen for visibility and traceability. Both 'collaboration and contractual agreements' and the systems for 'visibility and traceability' will influence how supply chain risk propagation will be contained and recovery will be initiated in case the sustainability factors are not met. The strand culminates into a proposition for academics to consider the industrial context when designing their research. These two strands are contained within the Systems Thinking approach (holistic approach) which helps to have a better understanding of interplay of the various factors affecting supply chains within the industrial context.

\section{CONCLUSION}

The SLR of 120 quality articles was conducted following a systematic research methodology. The SLR methodology was found to be driven by a methodical process and provides a strong evidence base. SLR supported with modern knowledge management tools allows a multi-dimensional analysis of the field to reveal patterns that are less clear in conventional literature study. An evident weakness of the methodology is that it puts greater stress on efficient data analysis may be weak in deciphering future challenges. The process is not just systematic but open and unbiased in drawing the definitive inferences.

The identified seven distinctive research factors are presented in a framework which is expected to provide researchers with hypothesis for future work. The factors in themselves can provide individual research areas within the area of SCRM. The culmination of the flow as shown in figure 7 is with regards to industry impact and it is the opinion of the authors that this is essential for future academic research. To provide industry with proactive and reactive management models to manage SCRM is essential and this will be possible by taking a holistic approach to understanding the challenges that supply chains face. The data analysis reported in the paper was based on evolved typologies and suggests a major growth of SCRM from a nascent to a fairly established stage over the past decade. The authors hope that the paper has established firm insights and clearly identified gaps and future directions into SCRM field. 
A. Ghadge, S. Dani and R. Kalawsky (2012), Supply Chain Risk Management: Present and Future Scope, International Journal of Logistics Management, Vol. 23 No. 3, pp. 313-339.

\section{Acknowledgement}

The authors gratefully thank the anonymous referees for comments and suggestions for improvements to the first version of this paper. They also acknowledge the guest editors.

\section{REFERENCES}

Agrell, P. (2004), "Risk, information and incentives in telecom supply chains", International Journal of Production Economics, Vol. 90 No. 1, pp.1-16.

Altay, N. and Green, W. (2006), "OR/MS research in disaster operations management", European Journal of Operational Research, Vol. 175 No. 1, pp. 475-493.

Ananiadou, S., Rea, B., Okazaki, N., Procter, R., and Thomas, J. (2009), "Supporting Systematic Reviews Using Text Mining”, Social Science Computer Review, Vol. 27 No. 4, pp. 509-523.

Anderberg, M. R. (1973), Cluster analysis for applications (probability and mathematical statistics monograph), Academic Press, New York.

Autry, C.W. and Bobbitt, L.M. (2008), "Supply chain security orientation: conceptual development and a proposed framework", The International Journal of Logistics Management, Vol. 19 No.1, pp. $42-64$.

Babich, V. (2006), "Vulnerable options in supply chains: Effects of supplier competition", Naval Research Logistics, Vol. 53 No. 7, pp.656-673.

Badger, D., Nursten, J., Williams, P., and Woodward, M. (2000), "Should all literature reviews be systematic?", Evaluation and Research in Education, Vol. 14 No.3, pp. 220-230.

Barbarosoglu, G. (2002), "An interactive approach for hierarchical analysis of helicopter logistics in disaster relief operations", European Journal of Operational Research, Vol. 140 No.1, pp.118133.

Blackhurst, J. , Craighead, C. W., Elkins, D. and Handfield, R. B. (2005), "An empirically derived agenda of critical research issues for managing supply-chain disruptions", International Journal of Production Research, Vol. 43 No.19, pp. 4067-4081.

Bogataj, D. and Bogataj, M. (2007), "Measuring the supply chain risk and vulnerability in frequency space", International Journal of Production Economics, Vol. 108 No.1, pp.291-301.

Braunscheidel, M.J. and Suresh, N.C. (2009), "The organizational antecedents of a firm's supply chain agility for risk mitigation and response", Journal of Operations Management, Vol. 27 No. 2, pp. 119-140.

Brun, A., Caridi, M., Salama, K. and Ravelli, I. (2006), "Value and risk assessment of supply chain management improvement projects", International Journal of Production Economics, Vol. 99 No. 2, pp.186-201.

Cachon, G.P. (2004), "The Allocation of Inventory Risk in a Supply Chain: Push, Pull, and AdvancePurchase Discount Contracts", Management Science, Vol. 50 No.2, pp.222-238.

Carter, M.W. and Price, C.C. (2001), Operations Research: A Practical Introduction, USA.

Cavinato, J. L. (2004), "Supply chain logistics risks: From the back room to the board room", International Journal of Physical Distribution and Logistics Management, Vol. 34 No. 5, pp.383387.

Chappell, A. and Peck, H. (2006), "Risk management in military supply chains: Is there a role for six sigma?", International Journal of Logistics Research and Applications, Vol. 9 No.3, pp.253-267. 
A. Ghadge, S. Dani and R. Kalawsky (2012), Supply Chain Risk Management: Present and Future Scope, International Journal of Logistics Management, Vol. 23 No. 3, pp. 313-339.

Chen, H., Fuller, S.S. and Friedman, C. (2001), Knowledge Management, Data Mining, And Text Mining in Medical Informatics, Springer, pp.3-33.

Chen, F.Y. and Yano, C. A. (2010), "Improving Supply Chain Performance and Managing Risk Under Weather-Related Demand Uncertainty", Management Science, Vol. 56 No.8, pp.1380-1397.

Childerhouse, P., Hermiz, R., Mason-Jones, R., Popp, A. and Towill, D. R. (2003), "Information flow in automotive supply chains- identifying and learning to overcome barriers to change", Industrial Management and Data Systems, Vol. 103 No. 7, pp. 491-502.

Choi, T. and Krause, D. (2006), "The supply base and its complexity: Implications for transaction costs, risks, responsiveness, and innovation", Journal of Operations Management, Vol. 24 No.5, pp. 637-652.

Chopra, S. and Sodhi, M. (2004), "Managing Risk To Avoid Supply Chain Breakdown", MIT Sloan Management Review, Vol. 46 No.1, pp. 53-61.

Chopra, S., Reinhardt, G. and Mohan, U. (2007), "The Importance of Decoupling Recurrent and Disruption Risks in a Supply Chain", Naval Research Logistics, Vol. 54 No. 5, pp. 544-555.

Christopher, M. and Lee, H. (2004), "Mitigating supply chain risk through improved confidence", International Journal of Physical Distribution and Logistics Management, Vol. 34 No.5, pp.388396.

Christopher, M. and Peck, H. (2004), "Building the Resilient Supply Chain", The International Journal of Logistics Management, Vol. 15 No.2, pp.1-14.

Christopher, M., Peck, H. and Towill, D. (2006), "A Taxonomy for Selecting Global Supply Chain Strategies", The International Journal of Logistics Management, Vol. 17 No.2, pp.277-287.

Cigolini, R. and Rossi, T. (2010), "Managing operational risks along the oil supply chain", Production Planning and Control, Vol. 21 No.5, pp.452-467.

Clarke, M. and A. D. Oxman (Eds) (2001), Cochrane Handbook for Systematic Reviews of Interventions', The Cochrane Collaboration. Oxford Library.

Colicchia, C., Dallari, F. and Melacini, M. (2010), "Increasing supply chain resilience in a global sourcing context", Production Planning and Control, Vol. 21 No.7, pp.680-694.

Colicchia, C. and Strozzi, F. (2012) "Supply chain risk management: a new methodology for a systematic literature review", Supply Chain Management: An International Journal, Vol. 17 No. 4, pp. 403- 418.

Cousins, P.D., Lamming, R.C. and Bowen, F. (2004), "The role of risk in environment-related supplier initiatives", International Journal of Operations and Production Management, Vol. 24 No.6, pp. 554-565.

Craighead, C.W., Blackhurst, J., Rungtusanatham, M.J., Handfield, R.B. (2007), "The severity of supply chain disruptions: design characteristics and mitigation capabilities", Decision Sciences, Vol. 38 No.1, pp.131-156.

Cruzes, D., Basili, V., Shull, F., and Jino, M. (2007), "Automated Information Extraction from Empirical Software Engineering Literature: Is That Possible?" First International Symposium on Empirical Software Engineering and Measurement, pp. 491-493.

Dani, S. and Deep, A. (2010), "Fragile food supply chains: reacting to risks", International Journal of Logistics Research and Applications, Vol. 13 No.5, pp.395-410.

Dani, S. (2008), "Predicting and Managing Supply Chain Risks", in Supply Chain Risk: A Handbook of Assessment, Management and Performance, Ritchie, R.L. and Zsidisin, G. (Eds), Springer. 
A. Ghadge, S. Dani and R. Kalawsky (2012), Supply Chain Risk Management: Present and Future Scope, International Journal of Logistics Management, Vol. 23 No. 3, pp. 313-339.

Datta, P.P., Christopher, M. and Allen, P. (2007), "Agent-based modelling of complex production/distribution systems to improve resilience", International Journal of Logistics Research and Applications, Vol. 10 No.3, pp.187-203.

Davies, P. (2000), The relevance of systematic reviews to educational policy and practice. Oxford Review of Education, Vol. 26, pp. 365-378.

Denyer, D. and Tranfield, D. (2009), "Producing a systematic review", in The Sage Handbook of Organizational Research Methods, Buchanan, D. and Bryman, A. (Eds), Sage Publications Ltd, London.

Hubbard, D. (2007), "How to Measure Anything: Finding the Value of Intangibles in Business", John Wiley and Sons, pp. 46.

Hubbard, D. (2009), "The Failure of Risk Management: Why It's Broken and How to Fix It", John Wiley and Sons.

Ellegaard, C. (2008), "Supply risk management in a small company perspective", Supply Chain Management: An International Journal, Vol. 13 No. 6, pp. 425-434.

Ellis, S.C., Henry, R.M. and Shockley, J. (2009), "Buyer perceptions of supply disruption risk: A behavioral view and empirical assessment", Journal of Operations Management, Vol. 28 No. 1, pp.34-46.

Ermoliev, Y.M., Ermolieva, T. Y., MacDonald, G. J., Norkin, V. I. and Amendola, A. (2000), "A system approach to management of catastrophic risks", European Journal of Operational Research, Vol. 122 No.2, pp.452-460.

Finch, P. (2004), "Case study Supply chain risk management", Supply Chain Management: An International Journal, No. 9, No. 2, pp.183-196.

Knight, F. H. (1921) "Risk, uncertainty and profit", Hart, Schaffner, and Marx Prize Essays, no. 31. Boston and New York: Houghton Mifflin, pp. 19.

Gan, X., Sethi, S.P. and Yan, H. (2004), "Coordination of Supply Chains with Risk-Averse Agents", Production and Operations Management, Vol. 13 No. 2, pp.135-149.

Gaudenzi, B. and Borghesi, A. (2006), "Managing risks in the supply chain using the AHP method", The International Journal of Logistics Management, Vol. 17 No.1, pp.114-136.

Ghadge, A., Dani, S. and Kalawsky, R. (2010), "A Framework for Managing Risks in the Aerospace Supply Chain Using Systems Thinking", Proceedings of the 5th International Conference on System of Systems Engineering, IEEE, Loughborough, UK.

Giaglis, G.M., Minis, I., Tatarakis, A. and Zeimpekis, V. (2004), "Minimizing logistics risk through realtime vehicle routing and mobile technologies: Research to date and future trends", International Journal of Physical Distribution and Logistics Management, Vol. 34 No. 9, pp.749 - 764

Giunipero, L.C. and Eltantawy, R.A. (2003), "Securing the upstream supply chain : a risk management approach", International Journal of Physical Distribution and Logistics Management, Vol. 34 No. 9, pp.698-713.

Goh, M., Lim, J.Y.S. and Meng, F. (2007), "A stochastic model for risk management in global supply chain networks", European Journal of Operational Research, Vol. 182 No. 1, pp.164-173.

Hale, T. and Moberg, C.R. (2005), "Improving supply chain disaster preparedness: A decision process for secure site location", International Journal of Physical Distribution and Logistics Management, Vol. 35 No. 3, pp.195-207. 
A. Ghadge, S. Dani and R. Kalawsky (2012), Supply Chain Risk Management: Present and Future Scope, International Journal of Logistics Management, Vol. 23 No. 3, pp. 313-339.

Hallikas, J., Karvonen, I., Pulkkinen, U., Virolainen, V. and Tuominen, M. (2004), "Risk management processes in supplier networks", International Journal of Production Economics, Vol. 90 No. 1, pp.47-58.

Hendricks, K B and Singhal, V. R. (2003), "The effect of supply chain glitches on shareholder wealth", Journal of Operations Management, Vol. 21 No. 5, pp.501-522.

Hendricks, K. B., Singhal, V. R. and Zhang, R. (2009), "The effect of operational slack, diversification, and vertical relatedness on the stock market reaction to supply chain disruptions", Journal of Operations Management, Vol. 27 No. 3, pp.233-246.

Hilmola, P., Helo, P. and Holweg, M. (2005) "On the outsourcing dynamics in the electronics sectors: the evolving role of the original design manufacturing", Working paper, Cambridge.

Hoenig, D. (2009), "An empirical analysis of supply chain risk management in the German automotive industry", International Journal of Production Economics, Vol. 131 No. 1, pp. $242-249$.

Hult, G.T.M. and Craighead, Christopher W. (2010), "Risk Uncertainty and Supply Chain Decisions : A Real Options Perspective", Decision Sciences, Vol. 41 No. 3, pp.435-458.

Hung, K.T. and Ryu, S. (2008), "Changing risk preferences in supply chain inventory decisions", Production Planning and Control, Vol. 19 No. 8, pp.770-780.

Jia, F. and Rutherford, C. (2010), "Mitigation of supply chain relational risk caused by cultural differences between China and the West", The International Journal of Logistics Management, Vol. 21 No. 2, pp.251-270.

Jiang, B, Belohlav, J. and Young, S. (2007), "Outsourcing impact on manufacturing firms' value: Evidence from Japan", Journal of Operations Management, Vol. 25 No. 4, pp.885-900.

Jiang, B, Baker, R.C. and Frazier, G.V. (2009), "An analysis of job dissatisfaction and turnover to reduce global supply chain risk: Evidence from China", Journal of Operations Management, Vol. 27 No. 2, pp.169-184.

Jonsson, P. (2000), "Towards an Holistic Understanding of Disruptions in Operations Management", Journal of Operations Management, Vol. 18 No. 6, pp.701-718.

Richey Jr, R. G. (2009), "The supply chain crisis and disaster pyramid: A theoretical framework for understanding preparedness and recovery", International Journal of Physical Distribution and Logistics Management, Vol. 39 No. 7, pp.619 - 628.

Juttner, U., Peck, H. and Christopher, M. (2003), "Supply chain risk management: outlining an agenda for future research", International Journal of Logistics Research and Applications, Vol. 6 No. 4, pp.197-210.

Juttner, U. (2005), "Supply chain risk management - Understanding the Business Requirements from a Practitioner Perspective", The International Journal of Logistics Management, Vol. 16 No.1, pp.120-141.

Kaya, M. and Özer, Ö. (2009), "Quality Risk in Outsourcing: Non contractible Product Quality and Private Quality Cost Information", Naval Research Logistics, Vol. 56 No.7, pp. 669-685.

Khan, O. and Burnes, B. (2007), "Risk and supply chain management: creating a research agenda", The International Journal of Logistics Management, Vol. 18 No. 2, pp.197-216.

Khan, O., Christopher, M. and Burnes, B. (2008), "The impact of product design on supply chain risk: a case study", International Journal of Physical Distribution and Logistics Management, Vol. 38 No. 5, pp.412-432. 
A. Ghadge, S. Dani and R. Kalawsky (2012), Supply Chain Risk Management: Present and Future Scope, International Journal of Logistics Management, Vol. 23 No. 3, pp. 313-339.

Kleindorfer, P.R. and Saad, G.H. (2005), "Managing Disruption Risks in Supply Chains", Production and Operations Management, Vol. 14 No. 1, pp.53- 68.

Knemeyer, A.M., Zinn, W. and Eroglu, C. (2009), "Proactive planning for catastrophic events in supply chains", Journal of Operations Management, Vol. 27 No. 2, pp.141-153.

Kull, T. and Closs, D. (2008), "The risk of second-tier supplier failures in serial supply chains: implications for order policies and distributor autonomy", European Journal of Operational Research, Vol. 186 No. 3, pp.1158-1174.

Laeequddin, M., Waheed, K.A. and Sahay, V. (2009), "Supply chain partners' trust building process through risk evaluation : the perspectives of UAE packaged food industry parties", Supply Chain Management: An International Journal, Vol. 14 No. 4, pp.280-290.

Lai, G., Debo, L. and Sycara, K. (2009), "Sharing inventory risk in supply chain: The implication of financial constraint", Omega: The International Journal of Management Science, Vol. 37 No. 4, pp. 811-825.

Lambert, D.M. and Pohlen, T.L. (2001), "Supply Chain Metrics", The International Journal of Logistics Management, Vol. 12 No.1, pp.1-19.

Lee, R.P. and Johnson, J.L. (2010), "Managing Multiple Facets of Risk in New Product Alliances", Decision Sciences, Vol. 41 No. 2, pp.271-300.

Lemmer, B., Grellier, R. and Steven, J. (1999), "Systematic review of non-random and qualitative research literature: Exploring and uncovering an evidence base for health visiting and decision making", Qualitative Health Research, Vol. 9 No. 3, pp. 315-328.

Leopoulos, V.N. and Kirytopoulos, K. A. (2004), "Risk management: a competitive advantage in the purchasing function", Production Planning and Control, Vol. 15 No. 7, pp.678-687.

Levary, R.R. (2007), "Ranking foreign suppliers based on supply risk", Supply Chain Management: An International Journal, Vol. 12 No. 6, pp.392-394.

Lewis, M. (2003), "Cause, consequence and control: towards a theoretical and practical model of operational risk", Journal of Operations Management, Vol. 21 No. 2, pp.205-224.

Li, J., Wang, S. and Cheng, T.C.E. (2010). "Competition and cooperation in a single-retailer twosupplier supply chain with supply disruption", International Journal of Production Economics, Vol. 124 No. 1, pp.137-150.

Liu, Z. and Nagurney, A. (2011), "Supply chain outsourcing under exchange rate risk and competition", Omega: The International Journal of Management Science, Vol. 39, pp.539-549.

Lockamy, A. and McCormack, K. (2010), "Analysing risks in supply networks to facilitate outsourcing decisions", International Journal of Production Research, Vol. 48 No. 2, pp.593-611.

Mantel, S., Tatikonda, M. and Liao, Y. (2006), "A behavioral study of supply manager decision-making: Factors influencing make versus buy evaluation", Journal of Operations Management, Vol. 24 No. 6, pp. 822-838.

Manuj, I. and Mentzer, J.T. (2008), "Global supply chain risk management strategies", International Journal of Physical Distribution and Logistics Management, Vol. 38 No. 3, pp.192-223.

Manuj, I., Mentzer, J.T. and Bowers, M.R. (2009), "Improving the rigor of discrete-event simulation in logistics and supply chain research", International Journal of Physical Distribution and Logistics Management, Vol. 39 No. 3, pp.172-201. 
A. Ghadge, S. Dani and R. Kalawsky (2012), Supply Chain Risk Management: Present and Future Scope, International Journal of Logistics Management, Vol. 23 No. 3, pp. 313-339.

Matook, S., Lasch, R. and Tamaschke, R. (2009), "Supplier development with benchmarking as part of a comprehensive supplier risk management framework", International Journal of Operations and Production Management, Vol. 29 No. 3, pp. 241-267.

Mauricio F. B., Mohammed Q., Wee, H.M. and Watanabe, K. (2009) "Supply chain risk management (SCRM): a case study on the automotive and electronic industries in Brazil", Supply Chain Management: An International Journal, Vol. 14 No. 4, pp. 247 - 252

Mingers, J. and White, L. (2010), "A Review of the Recent Contribution of Systems Thinking to Operational Research and Management Science", European Journal of Operational Research, Vol. 207 No 3, pp. 1147-1161.

Mudrageda, M. and Murphy, F.H. (2006), "Designing Safety Space in a Supply Chain to Handle System-Wide Disruptions", Naval Research Logistics, Vol. 54 No. 3, pp. 258- 264.

Nagurney, A., Cruz, J., Dong, J. and Zhang D. (2005), "Supply chain networks, electronic commerce, and supply side and demand side risk", European Journal of Operational Research, Vol. 164 No. 1 , pp.120-142.

Natarajarathinam, M., Capar, I. and Narayanan, A. (2009), "Managing supply chains in times of crisis: a review of literature and insights", International Journal of Physical Distribution and Logistics Management, Vol. 39 No. 7, pp.535-573.

(Noel) Bryson, K. (2002), "Using formal MS/OR modeling to support disaster recovery planning", European Journal of Operational Research, Vol. 141 No. 3, pp.679-688.

Neiger, D., Rotaru, K. and Churilov, L. (2009), "Supply chain risk identification with value-focused process engineering”, Journal of Operations Management, Vol. 27 No. 2, pp. 154-168.

Norrman, A. and Jansson, U. (2004), "Ericsson's proactive supply chain risk management approach after a serious sub-supplier accident", International Journal of Physical Distribution and Logistics Management, Vol. 34 No.5, pp.434-456.

Oehmen, J., Ziegenbein, A., Alard, R. and Schönsleben, P. (2009), "System-oriented supply chain risk management”, Production Planning and Control, Vol. 20 No. 4, pp. 343-361.

Ojala, M. and Hallikas, J. (2006), "Investment decision-making in supplier networks: Management of risk", International Journal of Production Economics, Vol. 104 No. 1, pp. 201-213.

Oke and Gopalakrishnan, M. (2009), "Managing disruptions in supply chains : A case study of a retail supply chain", International Journal of Production Economics, Vol.118 No. 1, pp. 168-174.

Oseibryson, K. and Ngwenyama, O. (2006), "Managing risks in information systems outsourcing: An approach to analyzing outsourcing risks and structuring incentive contracts", European Journal of Operational Research, Vol. 174 No. 1, pp. 245-264.

Papadakis, I.S. (2006), "Financial performance of supply chains after disruptions an event study", Supply Chain Management: An International Journal, Vol. 11 No. 1, pp. 25-33.

Peck, H. (2005), "Drivers of supply chain vulnerability: an integrated framework", International Journal of Physical Distribution and Logistics Management, Vol. 35 No. 4, pp. 210-232.

Peck, H. (2006), "Reconciling supply chain vulnerability, risk and supply chain management", International Journal of Logistics Research and Applications, Vol.9 No. 2, pp.127-142.

Perry, M. (2007), "Natural disaster management planning: A study of logistics managers responding to the tsunami", International Journal of Physical Distribution and Logistics Management, Vol. 37 No. 5, pp. 409-433. 
A. Ghadge, S. Dani and R. Kalawsky (2012), Supply Chain Risk Management: Present and Future Scope, International Journal of Logistics Management, Vol. 23 No. 3, pp. 313-339.

Ponomarov, S.Y. and Holcomb, M.C. (2009), "Understanding the concept of supply chain resilience", The International Journal of Logistics Management, Vol. 20 No. 1, pp.124-143.

Ponsporrata, a, Berlangallavori, R. and Ruizshulcloper, J. (2007), "Topic discovery based on text mining techniques", Information Processing and Management, Vol. 43 No. 3, pp. 752-768.

Pyke, D. and Tang, C. (2010), "How to mitigate product safety risks proactively? Process, challenges and opportunities", International Journal of Logistics Research and Applications, Vol. 13 No. 4, pp. 243-256.

Rao, S. and Goldsby, T.J. (2009), "Supply chain risks: a review and typology", The International Journal of Logistics Management, Vol. 20 No. 1, pp. 97-123.

Ravindran, A. R., Bilsel, R. U., Wadhwa, V. and Yang, T. (2010), "Risk adjusted multicriteria supplier selection models with applications", International Journal of Production Research, Vol. 48 No. 2, pp.405-424.

Ritchie, B. and Brindley, C. (2007), "Supply chain risk management and performance: A guiding framework for future development", International Journal of Operations and Production Management, Vol. 27 No. 3, pp.303-322.

Rousseau, D.M., Manning, J. and Denyer, D. (2008), "Evidence in management and organizational science: assembling the field's full weight of scientific knowledge through syntheses", The Academy of Management Annals, Vol. 2 No. 1, pp. 475-515.

Rowe, W.D. (1980), Risk assessment: approaches and methods, in Conrad, J. (Ed.), Society, Technology and Risk Assessment, Academic Press, London.

Sanchez-Rodrigues, V. and Naim, A.P. and M.M. (2010), "Evaluating the causes of uncertainty in logistics operations", The International Journal of Logistics Management, Vol. 21 No. 1, pp.4564.

Satty, T. L. (1990), "How to Make a Decision: The Analytic Hierarchy Process", European Journal of Operations Research, Vol.48, pp. 9-26.

Scheller-Wolf, A. and Tayur, S. (2009), "Risk sharing in supply chains using order bands- Analytical results and managerial insights", International Journal of Production Economics, Vol. 121 No. 2, pp.715-727.

Sheffi, Y. (2005), "A Supply Chain View of the Resilient Enterprise A Supply Chain View of the Resilient Enterprise", MIT Sloan Management Review, Vol. 47 No. 1, pp. 41-49.

Sheffi, Y. (2001), "Supply Chain Management under the Threat of International Terrorism", The International Journal of Logistics Management, Vol. 12 No. 2, pp.1-11.

Sinha, P.J., Whitman, L.E. and Malzahn, D. (2004), "Methodology to mitigate supplier risk in an aerospace supply chain", Supply Chain Management: An International Journal, Vol. 9 No. 2, pp.154-68.

Skipper, J.B. and Hanna, J.B. (2009), "Minimizing supply chain disruption risk through enhanced flexibility", International Journal of Physical Distribution and Logistics Management, Vol. 39 No. 5, pp. 404-427.

Sodhi, M.S. (2005), "Managing Demand Risk in Tactical Supply Chain Planning for a Global Consumer Electronics Company", Production and Operations Management, Vol. 14 No. 1, pp. $69-79$.

Sodhi. M. S., Son B-G and Tang C. S. (2012), "Researchers' Perspectives on Supply Chain Risk Management", Production and Operations Management, Vol 21 No. 1 pp. 1-13. 
A. Ghadge, S. Dani and R. Kalawsky (2012), Supply Chain Risk Management: Present and Future Scope, International Journal of Logistics Management, Vol. 23 No. 3, pp. 313-339.

Sounderpandian, J., Prasad, S. and Madan, M. (2008), "Supplies from developing countries: Optimal order quantities under loss risks", Omega: The International Journal of Management Science, Vol. 36 No. 1, pp.122-130.

Spekman, R.E. and Davis, E.W. (2004), "Risky business: expanding the discussion on risk and the extended enterprise", International Journal of Physical Distribution and Logistics Management, Vol. 34 No. 5, pp. 414-433.

Stefanovic, D., Stefanovic, N. and Radenkovic, B. (2009), "Supply network modelling and simulation methodology", Simulation Modelling Practice and Theory, Vol. 17 No. 4, 743-766.

Svensson, G. (2000), "A conceptual framework for the analysis of vulnerability in supply chains", International Journal of Physical Distribution and Logistics Management, Vol. 30 No. 9, pp.731750.

Svensson, G. (2002), "A conceptual framework of vulnerability in firms' inbound and outbound logistics flows", International Journal of Physical Distribution and Logistics Management, Vol. 32 No. 2, pp.110-134.

Tang, C. and Tomlin, B. (2008), "The power of flexibility for mitigating supply chain risks", International Journal of Production Economics, Vol. 116, No. 1, pp.12-27.

Tang, C. (2006a), "Robust strategies for mitigating supply chain disruptions", International Journal of Logistics Research and Applications, Vol. 9 No. 1, pp.33-45.

Tang, C. (2006b), "Perspectives in supply chain risk management", International Journal of Production Economics, Vol. 103 No. 2, pp.451-488.

Tang, O. and Nurmaya Musa, S. (2010), "Identifying risk issues and research advancements in supply chain risk management", International Journal of Production Economics, Vol. 133 No. 1, pp.2534.

Tapiero, C. (2007), "Consumers risk and quality control in a collaborative supply chain", European Journal of Operational Research, Vol. 182 No. 2, pp. 683-694.

The ABS Journal Guide. (2011), "ABS Academic Journal Quality Guide Version 4", available at: http://www.associationofbusinessschools.org/node/1000257 (accessed 25 September 2012).

Tomlin, B. (2006), "On the Value of Mitigation and Contingency Strategies for Managing Supply Chain Disruption Risks", Management Science, Vol. 52 No. 5, pp. 639-657.

Tomlin, B. (2009), "Disruption-Management Strategies for Short Life-Cycle Products", Naval Research Logistics, Vol. 56 No. 4, pp. 318-347

Torgerson, C. (2003), Systematic reviews, London: continuum.

Towill, D.R. (2005), "The impact of business policy on bullwhip induced risk in supply chain management", International Journal of Physical Distribution and Logistics Management, Vol. 35 No. 8, pp. 555-575.

Tranfield, D., Denyer, D. and Smart, P. (2003), "Towards a Methodology for Developing EvidenceInformed Management Knowledge by Means of Systematic Review", British Journal of Management, Vol.14 No. 3, 207-222.

Trkman, P. and Mccormack, K. (2009), "Supply chain risk in turbulent environments - A conceptual model for managing supply chain network risk", International Journal of Production Economics, Vol. 119 No. 2, pp. 247-258. 
A. Ghadge, S. Dani and R. Kalawsky (2012), Supply Chain Risk Management: Present and Future Scope, International Journal of Logistics Management, Vol. 23 No. 3, pp. 313-339.

Urciuoli, L. (2010), "Supply chain security-mitigation measures and a logistics multi-layered framework", Journal of Transportation Security, Vol. 3 No. 1, pp. 1-28.

Vanany, I., Zailani, S. and Pujawan, N. (2009), "Supply chain risk Management: Literature review and Future research", Int. Journal of Information Systems and Supply Chain Management, Vol. 2 No. 1, pp.16-33.

Vorst, J. G. A. J., Beulens, A. J. M., Wit, W. and Beek, P. (1998), "Supply Chain Management in Food Chains: Improving Performance by Reducing Uncertainty", International Transactions in Operational Research, Vol. 5 No.6, pp.487-499.

Vorst, J.G.A.J, and Beulens, A. J. M. (2002), "Identifying sources of uncertainty to generate supply chain redesign strategies", International Journal of Physical Distribution and Logistics Management, Vol. 32 No. 6, pp.409-430.

Wagner, S. M. and Bode, C. (2006), "An empirical investigation into supply chain vulnerability", Journal of Purchasing and Supply Management. Vol. 12 No 6, pp. 301-312.

Wagner, S.M., Bode, C. and Koziol, P. (2009), "Supplier default dependencies: Empirical evidence from the automotive industry", European Journal of Operational Research, Vol. 199 No. 1, pp.150-161.

Wagner, S.M. and Neshat, N. (2010), "Assessing the vulnerability of supply chains using graph theory". International Journal of Production Economics, Vol. 126 No. 1, pp.121-129.

Wakolbinger, T. and Cruz, J.M. (2011), "Supply chain disruption risk management through strategic information acquisition and sharing and risk-sharing contracts", International Journal of Production Research, Vol. 49 No. 13, pp. 4063-4084.

Wang, C.X. and Webster, S. (2007), "Channel Coordination for a Supply Chain with a Risk-Neutral Manufacturer and a Loss-Averse Retailer", Decision Sciences, Vol. 38 No. 3, pp.361-389.

Williams, Z., Lueg, J.E. and LeMay, S. A. (2008), "Supply chain security: an overview and research agenda", The International Journal of Logistics Management, Vol. 19 No. 2, pp.254-281.

Wilson, M. C. (2007), "The impact of transportation disruptions on supply chain performance", Transportation Research Part E: Logistics and Transportation Review, Vol. 43 No.4, pp. 295320.

Wu, T., Blackhurst, J. and O'grady, P. (2007), "Methodology for supply chain disruption analysis". International Journal of Production Research, Vol. 45 No. 7, pp.1665-1682.

Xiao, T. and Yang, D. (2008), "Price and service competition of supply chains with risk-averse retailers under demand uncertainty", International Journal of Production Economics, Vol. 114 No. 1, pp.187-200.

Yang, B. and Yang, Y. (2010), "Postponement in supply chain risk management: a complexity perspective", International Journal of Production Research, Vol. 48 No. 7, pp.1901-1912.

Yang, J., Qi, X. and Yu, G. (2005), "Disruption management in production planning", Naval Research Logistics, Vol. 52 No.5, pp.420-442.

Yang, Z., Aydin, G., Babich, V. and Beil, D. (2008), 'Supply Disruptions, Asymmetric Information, and a Backup Production Option”, Management Science, Vol. 55 No. 2, pp.192-209.

Yu, H., Zeng, and Zhao, L. (2009), "Single or dual sourcing: decision-making in the presence of supply chain disruption risks", Omega: The International Journal of Management Science, Vol. 37 No. 4, pp. $788-800$. 
A. Ghadge, S. Dani and R. Kalawsky (2012), Supply Chain Risk Management: Present and Future Scope, International Journal of Logistics Management, Vol. 23 No. 3, pp. 313-339.

Zsidisin, G.A. (2003a), "A grounded definition of supply risk", Journal of Purchasing and Supply Management, Vol. 9 No. 5, pp. 217-24.

Zsidisin, G. A. (2003b), "Managerial Perceptions of Supply Risk", The Journal of Supply Chain Management, Vol. 39 No. 1, pp.14-26.

Zsidisin, G.A., Ellram, L.M., Carter, J.R. and Cavinato, J.L. (2004), "An analysis of supply risk assessment techniques", International Journal of Physical Distribution and Logistics Management, Vol. 34 No. 5, pp. 397- 413.

Zsidisin, G.A., Panelli, A. and Upton, R. (2000), "Purchasing organisation involvement in risk assessments, contingency plans and risk management: an exploratory study", Supply Chain Management: An International Journal, Vol. 5 No. 4, pp. 187-197. 